\title{
Heavy metal concentrations and its impact on soil microbial and enzyme activities in agricultural lands around ship yards in Chattogram, Bangladesh
}

\author{
Nasrin Chowdhury*, Md. Mamunur Rasid \\ The University of Chittagong, Faculty of Biological Sciences, Department of Soil Science, Chittagong University Road, 4331, Chattogram, \\ Bangladesh \\ * Ph.D., Nasrin Chowdhury, nasrin@cu.ac.bd, ORCID iD: https://orcid.org/0000-0001-7345-8643
}

Received: 24.11.2020

Accepted: 21.04.2021

Associated editor: E. Błońska

\section{Keywords}

Agricultural soil, $\mathrm{ED}_{50}$ Microbial metabolic quotient Potential ecological risk index Ship scrap processing Soil enzyme

\begin{abstract}
The present endeavor was to evaluate the spatial distribution and ecological risk of heavy metals, released from ship scrap processing activities in agricultural soils of Sitakunda, Bangladesh. Soil samples were collected from 19 sites located in the vegetable garden, vegetable field and paddy field soils. The studied soils have the texture of sandy clay loam, extremely acidic to moderately acidic $\mathrm{pH}(4.23-5.88)$, soil organic matter was in the range from 0.79 to $1.43 \%$. The mean concentrations of all the heavy metals were higher than the standard limit value. Heavy metal concentrations ranged from 1.77 to $8.10 \mathrm{mg} \cdot \mathrm{kg}^{-1} \mathrm{Cd}, 102.75$ to $262.00 \mathrm{mg} \cdot \mathrm{kg}^{-1} \mathrm{Cr}, 90.52$ to $662.33 \mathrm{mg} \cdot \mathrm{kg}^{-1} \mathrm{Cu}, 26.66$ to $227.47 \mathrm{mg} \cdot \mathrm{kg}^{-1} \mathrm{Ni}, 148.33$ to $1483.33 \mathrm{mg} \cdot \mathrm{kg}^{-1} \mathrm{~Pb}$ and 270.37 to $1416.13 \mathrm{mg} \cdot \mathrm{kg}^{-1} \mathrm{Zn}$. The toxicity level of heavy metals in agricultural soils was, in order of decreasing concentration: $\mathrm{Cd}>\mathrm{Pb}>\mathrm{Cu}>\mathrm{Zn}>\mathrm{Ni}>$ $\mathrm{Cr}$. The principal component analysis evidenced that the heavy metal contaminants in agricultural soils may originate from the ship scrap dismantling and processing operations. All the heavy metals had shown a very high significant negative correlation with the number of cultivable bacteria and fungi, soil microbial biomass carbon, and microbial activity as well as the dehydrogenases, urease, acid phosphatase and arylsulfatase enzyme activities. Dehydrogenases activity was a very responsive enzymatic assay $(p<0.001)$ to ascertain the effect of contamination on the physiologically active soil microorganisms. The positively correlated quadratic relationship between metabolic quotient and heavy metal concentration designate adapted and metabolically less efficient microbial population developed due to long-term heavy metal pollution in these agricultural soils.
\end{abstract}

\section{Introduction}

Soil microbial and enzyme activities are the driving force controlling all biochemical activities in soil. These biological activities are strong indicators of soil productivity as they expeditiously react to environmental changes induced by pollution and contamination. An alteration of these activities may result in reduced soil quality (Wolińska et al., 2015). So, their estimation may provide useful information and be helpful to determine the effects of soil-specific environmental stress or management practices (Kuźniar et al., 2018). Some soil microbiological parameters: soil microbial biomass carbon (MBC), basal respiration (MA), bacterial families and genera (Wolińska et al., 2018) and enzyme activity (Akmal and Jianming, 2009) have been suggested as attainable indicators of soil quality and employed in the monitoring programs.
Soil pollution with heavy metals in different quantities and forms causes changes in the population and activity of microorganisms and enzymes, which is a true reflection of the actual microbiological condition of the soil (Kuźniar et al., 2018). Heavy metals can create abiotic stresses by inducing disorders in the metabolism of soil microorganisms when present in high concentrations. The results reported by Jiang et al., (2010) indicate that cadmium $(\mathrm{Cd})$, copper $(\mathrm{Cu})$ and zinc $(\mathrm{Zn})$ can disrupt the microbiological equilibrium of soil. Many researchers (Kuźniar et al., 2018; Wyszkowska et al., 2008) demonstrated that $\mathrm{Cd}$, $\mathrm{Cu}$ and $\mathrm{Zn}$, when present in excessive quantities in soil, cause disorders in the microbiological balance of the soil. There is a very close relationship between soil enzymes and soil microbes as enzymes secreted by microorganisms regulate the energy and nutrient cycle in the soil ecosystems. Soil enzymes are involved in synthesizing proteins, carbohydrates and nucleic acids and reg- 
ulate the decomposition of soil organic matter, releasing plant nutrients (Wolińska et al., 2015). Therefore, enzymatic activity can act as an indicator of soil health relating biological processes with physicochemical properties and stressed conditions which further can stipulate soil degradation. A high content of toxic heavy metals can inhibit the growth and reproduction of microorganisms by reducing the synthesis of the microbial enzyme or by modifying the enzyme-substrate complexes, enzyme protein and blocking active sites. When a metal enters the soil, it can alter the soil $\mathrm{pH}$ and usually results in acidification. Increasing heavy metal levels reduced soil enzyme activities were reported by Kuźniar et al., (2018).

Ship dismantling is initiated in Bangladesh in 1969 that experienced a boom in the 1980s and extends along the Sitakunda coast of Chattogram, Bangladesh. Ship dismantling activities and its scrap processing emerge many heavy metals that are found in many parts of ships such as in batteries, coatings, paints and electrical systems (Chowdhury and Rasid, 2016). Most of the ship wastes go to the informal sector as scrap and dumped beside workshops situated in the village vicinity of the shipyards for further processing. Monitoring is very strict in shipyards but the Government authority is not concerned about these workplaces. Ship scraps are scavenged for recycling by using primitive processes like unprotected acid leaching, manual dismantling and burning to recover worthwhile metals. Ship scrap processing sites are usually located in fields adjacent to land used for agricultural purposes. Heavy metals released could penetrate the soils where vegetables and rice are grown by contaminated irrigation water and through direct deposition by air, rainwater. Sitakunda is famous for agricultural products especially winter vegetables. Heavy metal contamination of these soils is of great concern as heavy metal contamination has a prolonged effect on soil ecology. Furthermore, an agricultural ecosystem has a close relationship with human health. Such distribution of heavy metals to the ambient area as well as on-site pollution may pose a direct agricultural and environmental hazard. The impact of hazardous substances, including heavy metals on beach soil and marine environment had been studied extensively (Alam et al., 2019; Rahman et al., 2019a, 2019b; Aktaruzzaman et al., 2014; Hasan et al., 2013). Similarly, higher concentrations of heavy metals such as cadmium, copper, lead, nickel and zinc were recorded in the adjacent areas of shipyards in Chattogram, Bangladesh (Chowdhury and Rasid, 2016; Alamgir et al., 2015), but there is no work on soil microbial and enzyme activity under this polluted area (Table 1). The present endeavor was to (a) compare the concentrations of metals determined, with background concentrations and standard limit values to show the extent of pollution (b) to assess the ecological risk by the heavy metals and (c) to determine the relationship of soil microbiological properties and four soil enzymatic activities (dehydrogenases, urease, acid phosphatase, arylsulfatase) from adjacent agricultural soils of ship dismantling area especially along the Dhaka-Chattogram highway to the heavy metal contamination, if there any. There are thousands of small unauthorized workshops, where opera-

Table 1

Comparison with reports of metal $(\mathrm{Cd}=$ Cadmium, $\mathrm{Cr}=$ Chromium, $\mathrm{Cu}=\mathrm{Copper}, \mathrm{Ni}=$ Nickel, $\mathrm{Pb}=\mathrm{Lead}, \mathrm{Zn}=\mathrm{Zinc})$ concentrations in Chattogram, Bangladesh.

\begin{tabular}{|c|c|c|c|c|c|c|c|}
\hline Land use type & $\mathrm{Cd}$ & $\mathrm{Cr}$ & $\mathrm{Cu}$ & $\mathrm{Ni}$ & $\mathrm{Pb}$ & $\mathrm{Zn}$ & Reference \\
\hline & & & & $\mathrm{mg} \cdot \mathrm{kg}^{-1}$ & & & \\
\hline \multirow[t]{7}{*}{ Shipyard } & $5.50-9.30$ & $250.80-160.00$ & $180.20-155.90$ & $90.80-67.00$ & $103.10-134.60$ & $713.30-883.10$ & Alam et al., 2019 \\
\hline & - & 7.95-19.22 & 15.4-21.95 & - & $65.50-116.90$ & 560.00 & Rahman et al., 2019a \\
\hline & 0.26 & 94.90 & 86.90 & 53.00 & 339.70 & 560.00 & Rahman et al., 2019b \\
\hline & BDL & $39.78-223.18$ & $25.25-83.36$ & - & $16.39-85.83$ & 37.05-103.88 & Aktaruzzaman et al., 2014 \\
\hline & $0.01-1.16$ & $311-1232$ & $6.00-1635.00$ & $8.00-45.00$ & $16.00-22.00$ & $58.00-978.00$ & Hasan et al., 2013 \\
\hline & $0.55-3.95$ & $0.60-65.20$ & BDL-295.65 & $16.30-162.20$ & BDL-137.05 & $33.25-305.10$ & Ahmed et al., 2013 \\
\hline & $0.09-0.18$ & $1.06-2.40$ & $2.32-3.96$ & $1.26-2.16$ & $3.42-6.03$ & $1.89-2.70$ & Hossain and Islam 2006 \\
\hline \multirow[t]{2}{*}{ Agricultural } & $0.14-1.39$ & $37.20-113.70$ & $32.40-555.80$ & $33.50-82.10$ & $19.50-287.00$ & $181.60-3648.40$ & Hasan et al., 2020 \\
\hline & $0.21-6.20$ & $10.70-190$ & 28.81-919.02 & $9.36-120.00$ & $148.70-1694.33$ & $41.73-331.56$ & Chowdhury and Rasid 2016 \\
\hline \multirow[t]{3}{*}{ City area } & - & $17.70-99.08$ & $20.34-33.06$ & $34.10-41.27$ & $23.66-25.05$ & $59.69-74.32$ & Wang et al., 2016 \\
\hline & $0.52-4.84$ & - & $4.68-74.33$ & 13.17-2551.96 & $3.63-13.40$ & $23.20-402.95$ & Alamgir et al., 2015 \\
\hline & $0.50-1.20$ & - & $37.00-42.00$ & - & $70.00-82.00$ & $248.00-317.00$ & Alam et al., 2012 \\
\hline \multicolumn{8}{|c|}{ Standard value for agricultural soil } \\
\hline China & 0.30 & $\begin{array}{c}\text { Dry soil } 200.00 \\
\text { Paddy soil } 150.00\end{array}$ & 100.00 & 50.00 & 300.00 & 250.00 & Chen et al., 2018 \\
\hline Netherlands & 0.80 & 100.00 & 36.00 & 35.00 & 85.00 & 140.00 & VROM 2000 \\
\hline Canada & 1.40 & 64.00 & 63.00 & 50.00 & 140.00 & 200.00 & CCME 2003 \\
\hline Australia & 3.00 & 50.00 & 60.00 & 60.00 & 300.00 & 200.00 & DEC 2010 \\
\hline
\end{tabular}

Explanation: BDL - Below detectable level. 
tions of ship scrap processing are going on all year-round. Most uncontrolled ship scrap processing sites are located in or close to agricultural land where rice and vegetables are grown regularly. It is hypothesized that these soils may lack different nutrient cycling enzymes for high heavy metal contamination and that may also affect the soil quality and nutrient cycle in soil.

\section{Materials and methods}

\subsection{Description of the study area}

A segment of the area covering the villages beside the shipyards to the stalls selling the goods and scraps from ships and scrap processing workshops along with Dhaka-Chattogram highway in Sitakunda, Chattogram ( $22^{\circ} 37^{\prime} \mathrm{N}$ and $91^{\circ} 39.7^{\prime} \mathrm{E}$ longitude) (Fig. 1) was selected for the study. According to the United States Department of Agriculture (USDA) soil classification system, the soils analyzed in the study were classified as the Lithic Ustochrepts (Huq and Shoaib, 2013). The topography of Sitakunda is hill with elevations ranging from 50 to $150 \mathrm{~m}$ above sea level. There is a tropical monsoon climate (Misbahuzzaman and Alam, 2006) with an average maximum temperature is $32.3^{\circ} \mathrm{C}$ during May, and the minimum, $13.9^{\circ} \mathrm{C}$ in January. The annual average rainfall is $2890 \mathrm{~mm}$. The active uncontrolled processing of ship scraps had left open incineration sites scattered among agricultural fields, and ship wastes dumped beside the ponds. Amid

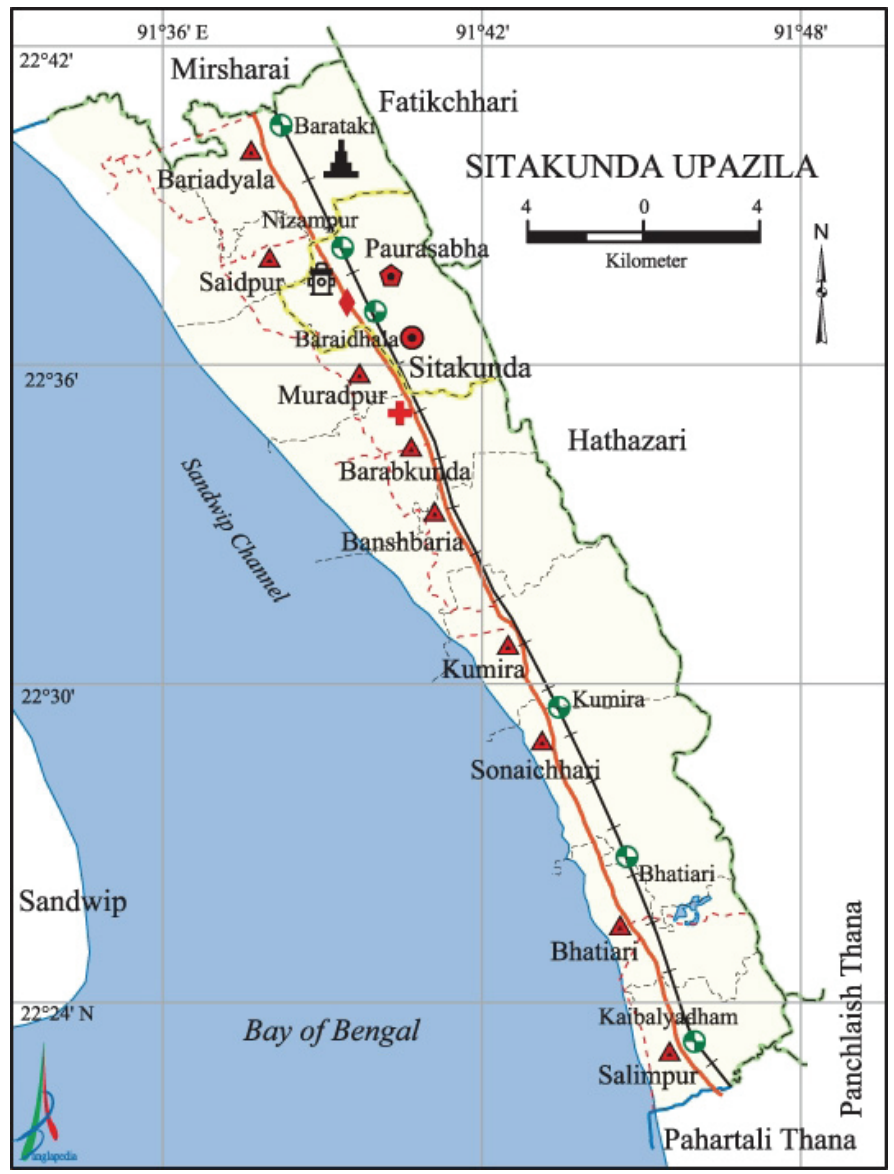

the ship scrap recycling activities, agricultural operations, such as planting rice and vegetables were taking place in the area. Spots for soil sampling were selected based on visual activities of ship scarp processing. Soil samples were collected from agricultural fields adjacent to ship scrapping operational sites. These areas were continuously receiving discharge from the working area. All of the sampling locations in the present study can be classified into three groups: vegetable field, paddy field around scrap processing or dumping sites and vegetable garden near the homestead area.

\subsection{Soil sampling and processing}

The soil samples (topsoil, 0-15 cm) were collected from nineteen sites (Table 2), including one comparison sample reference site (C), which was not polluted by heavy metals. From the vegetable garden, vegetable field and paddy fields, eight (VG1-VG8), six (VF1-VF6) and four (P1-P4) sites were selected respectively. Three soil subsamples, five kilograms each were collected from the sites. Soil sampling was done with a stainless-steel spade. All of the samples were put in polythene bags and transported to the laboratory on the day of sampling. The composite soil samples were sieved through a $2 \mathrm{~mm}$ sieve, homogenized, a portion of this was air-dried for physical and chemical analysis another portion was ground to pass through a $1 \mathrm{~mm}$ sieve, adjusting to $45 \%$ of water holding capacity, stored in polythene bags at $4^{\circ} \mathrm{C}$ before soil microbial and enzymatic activities analysis.

Fig. 1. Location of the study area (website 1) 
Table 2

Site legend, locations and soil reaction (pH), soil organic matter (SOM), total nitrogen (TN), available phosphorus (AvP) and clay content (Clay) values (mean \pm SD) of different agricultural soils besides ship scrap processing sites, Sitakunda, Chattogram.

\begin{tabular}{|c|c|c|c|c|c|c|c|}
\hline \multirow[t]{2}{*}{ Legend } & \multirow[t]{2}{*}{ Site } & \multirow[t]{2}{*}{$\mathrm{pH}$} & SOM & $\mathrm{TN}$ & $\mathrm{AvP}$ & Clay & \multirow[t]{2}{*}{ Soil Texture } \\
\hline & & & $\%$ & $\%$ & $\mathrm{mg} \cdot \mathrm{kg}^{-1}$ & $\%$ & \\
\hline \multicolumn{8}{|c|}{ Vegetable garden (VG) } \\
\hline VG1 & Acid-leaching site & $4.23 \pm 0.03^{\mathrm{a}}$ & $0.91 \pm 0.02^{\mathrm{bc}}$ & $0.10 \pm 0.01^{\mathrm{a}}$ & $5.95 \pm 0.56^{\mathrm{a}}$ & $27.41 \pm 0.25^{\mathrm{a}}$ & Sandy clay loam \\
\hline VG2 & Burning site & $4.35 \pm 0.01^{b}$ & $0.93 \pm 0.00^{\mathrm{bc}}$ & $0.13 \pm 0.02^{\mathrm{b}}$ & $5.95 \pm 0.08^{a}$ & $27.98 \pm 0.04^{\mathrm{b}}$ & Sandy clay loam \\
\hline VG3 & Dismantling site & $4.55 \pm 0.01^{c}$ & $0.93 \pm 0.00^{\text {bc }}$ & $0.13 \pm 0.01^{\mathrm{b}}$ & $6.95 \pm 0.05^{\mathrm{b}}$ & $28.13 \pm 0.06^{\mathrm{bc}}$ & Sandy clay loam \\
\hline VG4 & Burnt plastic dump site & $5.83 \pm 0.02^{p}$ & $1.41 \pm 0.09^{h}$ & $0.17 \pm 0.00^{\mathrm{fg}}$ & $12.18 \pm 0.02^{\mathrm{jk}}$ & $31.03 \pm 0.67^{\mathrm{i}}$ & Sandy clay loam \\
\hline VG5 & Metal workshop/processing site & $4.64 \pm 0.01^{\mathrm{e}}$ & $0.80 \pm 0.01^{\mathrm{a}}$ & $0.14 \pm 0.00^{\mathrm{bc}}$ & $8.08 \pm 0.03^{c}$ & $28.61 \pm 0.09^{d}$ & Sandy clay loam \\
\hline VG6 & Electric waste dumping site & $4.96 \pm 0.01^{\mathrm{k}}$ & $1.29 \pm 0.00^{\mathrm{g}}$ & $0.15 \pm 0.00^{\text {cde }}$ & $10.15 \pm 0.13^{f}$ & $29.06 \pm 0.04^{\mathrm{efg}}$ & Sandy clay loam \\
\hline VG7 & Scrap dumping site & $4.72 \pm 0.01^{\mathrm{g}}$ & $1.05 \pm 0.01^{\mathrm{ef}}$ & $0.14 \pm 0.00^{\mathrm{bcd}}$ & $8.53 \pm 0.13^{\mathrm{d}}$ & $28.85 \pm 0.04^{\mathrm{de}}$ & Sandy clay loam \\
\hline VG8 & Waste oil processing site & $4.87 \pm 0.02^{i}$ & $0.90 \pm 0.01^{b c}$ & $0.14 \pm 0.00^{\mathrm{bcd}}$ & $9.03 \pm 0.06^{\mathrm{e}}$ & $29.00 \pm 0.00^{\mathrm{efg}}$ & Sandy clay loam \\
\hline \multicolumn{8}{|c|}{ Vegetable field (VF) } \\
\hline VF1 & Burning site & $4.80 \pm 0.02^{h}$ & $0.89 \pm 0.00^{\mathrm{b}}$ & $0.15 \pm 0.00^{\text {def }}$ & $11.34 \pm 0.02^{\mathrm{h}}$ & $28.94 \pm 0.05^{\mathrm{ef}}$ & Sandy clay loam \\
\hline VF2 & Dismantling site & $4.91 \pm 0.01^{j}$ & $0.93 \pm 0.01^{b c}$ & $0.18 \pm 0.01^{g}$ & $10.54 \pm 0.13^{g}$ & $29.00 \pm 0.00^{\mathrm{efg}}$ & Sandy clay loam \\
\hline VF3 & Acid-leaching site & $4.67 \pm 0.01^{\mathrm{f}}$ & $0.95 \pm 0.18^{\mathrm{bcd}}$ & $0.15 \pm 0.00^{\text {def }}$ & $11.77 \pm 0.01^{\mathrm{k}}$ & $28.78 \pm 0.03^{\mathrm{de}}$ & Sandy clay loam \\
\hline VF4 & Metal workshop & $4.97 \pm 0.02^{k}$ & $0.98 \pm 0.00^{\text {bcde }}$ & $0.15 \pm 0.00^{\text {cde }}$ & $11.40 \pm 0.05^{\mathrm{i}}$ & $29.10 \pm 0.00^{\mathrm{efg}}$ & Sandy clay loam \\
\hline VF5 & Scrap dumping site & $5.02 \pm 0.00^{1}$ & $1.00 \pm 0.01^{\text {cde }}$ & $0.14 \pm 0.02^{\mathrm{bcd}}$ & $11.73 \pm 0.11^{\mathrm{i}}$ & $29.23 \pm 0.12^{\mathrm{fg}}$ & Sandy clay loam \\
\hline VF6 & Electric waste dumping site & $5.11 \pm 0.02 \mathrm{~m}$ & $1.03 \pm 0.03^{\text {def }}$ & $0.15 \pm 0.00^{\text {def }}$ & $12.05 \pm 0.05^{j}$ & $29.32 \pm 0.02^{\mathrm{g}}$ & Sandy clay loam \\
\hline \multicolumn{8}{|c|}{ Paddy field sites (P) } \\
\hline $\mathrm{P} 1$ & Scrap dumping site & $5.72 \pm 0.01^{n}$ & $1.27 \pm 0.03^{g}$ & $0.16 \pm 0.00^{\mathrm{ef}}$ & $12.25 \pm 0.05^{\mathrm{jk}}$ & $31.43 \pm 0.06^{j}$ & Sandy clay loam \\
\hline $\mathrm{P} 2$ & Electric waste dumping site & $5.76 \pm 0.02^{\circ}$ & $1.23 \pm 0.01^{\mathrm{g}}$ & $0.17 \pm 0.01^{g}$ & $12.36 \pm 0.05^{\mathrm{k}}$ & $31.57 \pm 0.06^{\mathrm{j}}$ & Sandy clay loam \\
\hline P3 & Metal workshop site & $4.59 \pm 0.02^{\mathrm{d}}$ & $1.11 \pm 0.01^{\mathrm{f}}$ & $0.15 \pm 0.00^{\text {bcde }}$ & $11.25 \pm 0.00^{\mathrm{h}}$ & $28.32 \pm 0.09^{c}$ & Sandy clay loam \\
\hline $\mathrm{P} 4$ & Product storage site & $5.88 \pm 0.02$ q & $1.43 \pm 0.01^{\mathrm{h}}$ & $0.24 \pm 0.01^{\mathrm{i}}$ & $13.06 \pm 0.03^{\mathrm{m}}$ & $30.01 \pm 0.11^{\mathrm{h}}$ & Sandy clay loam \\
\hline \multicolumn{8}{|c|}{ Reference site (C) } \\
\hline $\mathrm{C}$ & $10 \mathrm{~km}$ away from the recycling site & $5.96 \pm 0.04^{\mathrm{r}}$ & $1.51 \pm 0.02^{\mathrm{i}}$ & $0.21 \pm 0.01^{\mathrm{h}}$ & $12.78 \pm 0.08^{1}$ & $29.82 \pm 0.03^{h}$ & Sandy clay loam \\
\hline \multicolumn{8}{|c|}{ Land use types } \\
\hline & Vegetable garden & $4.77 \pm 0.47^{\mathrm{x}}$ & $1.03 \pm 0.20^{\mathrm{x}}$ & $0.14 \pm 0.02^{\mathrm{x}}$ & $8.35 \pm 2.05^{x}$ & $28.76 \pm 1.05^{x}$ & Sandy clay loam \\
\hline & Vegetable field & $4.91 \pm 0.15^{\mathrm{x}}$ & $0.96 \pm 0.08^{x}$ & $0.15 \pm 0.01^{x}$ & $11.47 \pm 0.50^{y}$ & $29.06 \pm 0.19^{x y}$ & Sandy clay loam \\
\hline & Paddy field & $5.49 \pm 0.54^{y}$ & $1.26 \pm 0.12^{\mathrm{y}}$ & $0.18 \pm 0.04^{y}$ & $12.23 \pm 0.68^{y}$ & $30.33 \pm 1.37^{z}$ & Sandy clay loam \\
\hline & Reference & $5.96 \pm 0.04^{z}$ & $1.51 \pm 0.02^{z}$ & $0.21 \pm 0.01^{z}$ & $12.78 \pm 0.08^{y}$ & $29.82 \pm 0.03^{\mathrm{yz}}$ & Sandy clay loam \\
\hline
\end{tabular}

Values in the same column followed by the same letter(s) are not significantly different at $p<0.05$ according to ANOVA.

\subsection{Analysis}

General soil characteristics were determined following the standard procedures. The $\mathrm{pH}$ of the soil samples was measured by $\mathrm{pH}$ meter at dry soil and distilled water ratio of $1: 5$ as described in Jackson (1973). Particle size distributions of the soils were determined by the hydrometer method (Day, 1965). Textural classes were determined using "soil automatic texture calculator” by Natural Resources Conservation Service Soils of the United States Department of Agriculture (website 2). The organic carbon (OC) content of the soil samples was determined volumetrically by the wet oxidation method by Nelson and Sommers (1982). Organic matter content was estimated through the use of an approximate correction factor, the "Van Bemmelen factor" of 1.724 which is based on the assumption that organic matter contains 58 percent OC. Total nitrogen (TN) content in soil was determined by the Micro-Kjeldahl method following $\mathrm{H}_{2} \mathrm{SO}_{4}$ acid digestion and alkali distillation and available phosphorus (AvP) by the colorimetric method after digestion with hydrofluoric and perchloric acid (Jackson, 1973). The total concentrations of metals were determined by Atomic Absorption Spectrophotometer (Aligent 240) after strong acid digestion (1:1 mixture of concentrated nitric and perchloric acids) of $200 \mathrm{mg}$ of soil samples. The digested samples were filtered and collected in $5 \mathrm{ml}$ of $2.0 \mathrm{M}$ HCL as in Ure (1990). 


\subsubsection{Measurement of soil microbiological properties}

Numbers of total bacteria and fungi in soils were counted using the dilution plate method as described in Johnson and Curl (1972). Nutrient agar (NA) medium was used with bacteria and potato dextrose agar (PDA) medium with fungi. Three plates were used for each dilution. The plates were incubated at $28^{\circ} \mathrm{C}$ for 7-10 days and counting made for forming colonies. MBC was measured by the method described by Anderson and Ingram (1993). The microbial cells in soil were killed by fumigation with ethanol-free chloroform. Immediately after pre-incubation, duplicate portions of soil, $5 \mathrm{~g}$ for each were taken in falcon tubes. One set of samples was fumigated with ethanol-free chloroform for $24 \mathrm{~h}$ at $25^{\circ} \mathrm{C}$ in a sealed desiccator. Non fumigated set of samples in falcon tubes were capped and stored at $8^{\circ} \mathrm{C}$. After fumigant removal, both fumigated and non-fumigated soils were extracted with freshly prepared $0.5 \mathrm{M}$ potassium sulfate at 1:4 ratios and filtered. Dissolved OC in the extracts was determined after dichromate digestion by titrating with $0.03 \mathrm{M}$ acidified ferrous ammonium sulfate. The amount of soil MBC was calculated from the difference between the extracted carbon from chloroform fumigated and non-fumigated samples. MA was determined by trapping the $\mathrm{CO}_{2}$ in $\mathrm{NaOH}$ which were evolved from the soil during incubation in a closed system (Alef and Nannipieri, 1995). The trapped $\mathrm{CO}_{2}$ was determined by measuring electrical conductivity (Rodella and Saboya, 1999). For this purpose, $50 \mathrm{~g}$ (oven-dry basis) moist pre-incubated (60\% of water holding capacity for 10 days) soil was placed in 1-liter capacity incubation Jars. Ten $\mathrm{ml}$ of $1.0 \mathrm{M} \mathrm{NaOH}$ solution in $50 \mathrm{ml}$ falcon tubes were placed in each jar as the $\mathrm{CO}_{2}$ trap. A falcon tube with water was added into the jar to maintain the soil moisture. Jars were made airtight immediately. Two jars with $1.0 \mathrm{M} \mathrm{NaOH}$ but without soil were used as controls. All jars were incubated at $25^{\circ} \mathrm{C}$. $\mathrm{CO}_{2}$ absorbed in traps was analyzed at 1, 7, 14, 30 days of $\mathrm{NaOH}$ placement. Each time fresh $\mathrm{NaOH}$ solution $(10 \mathrm{ml})$ was replaced to trap $\mathrm{CO}_{2}$ for the next days. In this method $\mathrm{CO}_{2}$ evolved from each sample was calculated as the difference between the initial and the $\mathrm{CO}_{2}$ concentration after each measurement period. The substrate-induced respiration (SIR) of the soils was assessed according to the rate of the maximal initial respiration of the microorganism after the enrichment of the soils with $0.5 \%$ glucose (West and Sparling, 1986). Over the first $2 \mathrm{~h}$, the increase in $\mathrm{CO}_{2}-\mathrm{C}$ is proportional to the size of the initial $\mathrm{MBC}$ concentration. Respiration was determined by trapping the $\mathrm{CO}_{2}$ in $\mathrm{NaOH}$ as in MA.

\subsubsection{Measurement of soil enzyme activities}

Soil dehydrogenase activity was determined by the procedure of Casida (1977). Soil samples were suspended in a triphenyl tetrazolium chloride solution and incubated for $6 \mathrm{~h}$ at $37^{\circ} \mathrm{C}$. The triphenyl formazan (TPF) produced was extracted with methanol and measured photometrically at $485 \mathrm{~nm}$. Urease activity was assayed according to the method of Tabatabai and Bremner (1972). After the addition of a buffered urea solution, soil samples were incubated for $2 \mathrm{~h}$ at $37^{\circ} \mathrm{C}$. The filtrated solution was distilled with $\mathrm{MgO}$. The produced $\mathrm{NH}_{4}{ }^{+}-\mathrm{N}$ was collected into a boric acid indicator solution and titrated with diluted
$\mathrm{H}_{2} \mathrm{SO}_{4}$ to determine the $\mathrm{NH}_{4}^{+}-\mathrm{N}$. Acid phosphatases activity was measured using the method of Eivazi and Tabatabai (1977). After the addition of a buffered p-nitrophenyl phosphate solution (pH 6.5), soil samples were incubated for $1 \mathrm{~h}$ at $37^{\circ} \mathrm{C}$. The $\mathrm{p}$-nitrophenol released by phosphomonoesterase activity was extracted and colored with $\mathrm{NaOH}$ and was measured photometrically at $400 \mathrm{~nm}$. Arylsulfatase activity was measured by the potassium p-nitrophenyl sulfate method (Tabatabai and Bremner, 1970). After the addition of a buffered potassium p-nitrophenyl sulfate (pH 5.8), soil samples were incubated for $1 \mathrm{~h}$ at $37^{\circ} \mathrm{C}$. The P-nitrophenol released by phosphomonoesterase activity was extracted and colored with $\mathrm{NaOH}$ and was measured photometrically at $400 \mathrm{~nm}$.

\subsubsection{Ecological risk assessment for soil pollution}

Pollution levels of $\mathrm{Cd}, \mathrm{Cu}, \mathrm{Cr}, \mathrm{Ni}, \mathrm{Pb}$ and $\mathrm{Zn}$ in the soil samples were evaluated using heavy metal indices, such as contamination factor $\left(C_{f}^{i}\right)$, degree of contaminations $\left(C_{d}\right)$, pollution load index (PLI), total load of extractable metals (TLM) and geo-accumulation index $\left(I_{g e o}\right)$, which are widely used to estimate the contamination levels of heavy metals in agricultural soils (Adimalla and Li, 2019).

\subsubsection{Contamination factor $\left(C_{f}^{i}\right)$}

The contamination factor may be defined as the ratio of the metal concentration in the soil to that of background value. According to the intensities of contamination, the levels of contamination may be divided into six categories (Table 3) (Islam et al., 2015). Thus, the $C_{f}^{i}$ values show the enrichment of heavy metals in soils of a certain place.

$$
C_{f}^{i}=\frac{C_{\text {Heavy metal }}}{C_{\text {Background }}}
$$

where, $C_{f}^{i}=$ Contamination factor, $C_{\text {Heavy metal }}=$ the content of the heavy metal in samples, $C_{\text {Background }}=$ the background value of the heavy metal.

\subsubsection{Potential Ecological Risk (PER) index}

The degrees of heavy metal contamination in agricultural soils can be evaluated with $P E R$ index. The sensitivity of the biological community can be expressed by it to the heavy metal stress and indicates the potential ecological risk caused by the overall heavy metal contamination. The equations which were used to calculate PER are as follows (Guo et al., 2010):

$$
P E R=\sum_{i=1}^{m} E_{r}^{i} \quad C_{f}^{i}=\frac{C^{i}}{C_{n}^{i}} \quad C_{d}=\sum_{i=1}^{n} C_{f}^{i} \quad E_{r}^{i}=T_{r}^{i} \times C_{f}^{i}
$$

where, $P E R=$ comprehensive potential ecological risk index, $C_{f}^{i}$ = single heavy metal contamination factor, $C^{i}=$ content of the heavy metal in samples, $C_{n}^{i}=$ background value of the heavy metal, $C_{d}=$ degree of contaminations, $E_{r}^{i}=$ potential ecological risk index, $T_{r}^{i}=$ biological toxic factor, the biological toxic factors for cadmium $=30$, chromium $=2$, copper $=5$, nickel $=6$, lead $=5$, and zinc = 1 (Guo et al., 2010, Islam and Hoque, 2014). 
Table 3

Indices and grades of potential ecological risk of heavy metal pollution (Islam et al., 2015)

\begin{tabular}{|c|c|c|c|c|c|c|c|c|c|}
\hline \multicolumn{4}{|c|}{ Potential Ecological Risk index (PER) } & \multicolumn{4}{|c|}{ Degree of Contamination $\left(C_{d}\right)$} & \multicolumn{2}{|c|}{$\begin{array}{l}\text { Geo-accumulation index } \\
\qquad\left(I_{\mathrm{geo}}\right)\end{array}$} \\
\hline$E_{r}^{i}$ & Grade & $P E R$ & Grade & $C_{f}^{i}$ & Degree & $C_{d}$ & Degree & $I_{\text {geo }}$ & Degree \\
\hline $\mathrm{E}_{\mathrm{r}}^{\mathrm{i}}<40$ & Low & $\mathrm{RI}<65$ & Low & $\mathrm{C}_{\mathrm{f}}^{\mathrm{i}}<1$ & Low & $C_{d}<5$ & Low & $I_{\text {geo }}<0$ & $\begin{array}{l}\text { Practically } \\
\text { uncontaminated }\end{array}$ \\
\hline $40 \leq \mathrm{E}_{\mathrm{r}}^{\mathrm{i}}<80$ & Moderate & $65 \leq \mathrm{RI}<130$ & Moderate & $1 \leq \mathrm{C}_{\mathrm{f}}^{\mathrm{i}}<3$ & Moderate & $5 \leq C_{d}<10$ & Moderate & $0<I_{\mathrm{geo}}<1$ & $\begin{array}{l}\text { Uncontaminated } \\
\text { to moderately } \\
\text { contaminated }\end{array}$ \\
\hline $80 \leq \mathrm{E}_{\mathrm{r}}^{\mathrm{i}}<160$ & Considerable & $130 \leq \mathrm{RI}<260$ & Considerable & $3 \leq \mathrm{C}_{\mathrm{f}}^{\mathrm{i}}<6$ & Considerable & $10 \leq C_{d}<20$ & Considerable & $1<I_{\text {geo }}<2$ & $\begin{array}{l}\text { Moderately } \\
\text { contaminated }\end{array}$ \\
\hline $160 \leq \mathrm{E}_{\mathrm{r}}^{\mathrm{i}}<320$ & High & $\mathrm{RI} \geq 260$ & Very high & $\mathrm{C}_{\mathrm{f}}^{\mathrm{i}} \geq 6$ & High & $C_{d} \geq 20$ & High & $2<I_{\text {geo }}<3$ & $\begin{array}{l}\text { Moderately } \\
\text { to heavily } \\
\text { contaminated }\end{array}$ \\
\hline \multirow[t]{3}{*}{$\mathrm{E}_{\mathrm{r}}^{\mathrm{i}} \geq 320$} & Very high & & & & & & & $3<I_{\text {geo }}<4$ & $\begin{array}{l}\text { Heavily } \\
\text { contaminated }\end{array}$ \\
\hline & & & & & & & & $4<I_{\text {geo }}<5$ & $\begin{array}{l}\text { Heavily to } \\
\text { extremely } \\
\text { contaminated }\end{array}$ \\
\hline & & & & & & & & $I_{\mathrm{geo}}>5$ & $\begin{array}{l}\text { Extremely } \\
\text { contaminated }\end{array}$ \\
\hline
\end{tabular}

\subsubsection{Pollution Load Index (PLI)}

The pollution load index ( $P L I)$ acts as an integrated approach that expresses soil quality with the response to the heavy metals. The $P L I$ is a calculation as the nth root of the multiplications of the contamination factor $\left(C_{f}^{i}\right)$ of heavy metals (Suresh et al., 2015). The $P L I$ value of zero indicates perfection, a value of one indicates the presence of only the baseline level of pollutants and values above one would indicate progressive deterioration of the soil quality (Proshad et al., 2019).

$$
P L I=\left(C_{f 1}^{i} \times C_{f 2}^{i} \times C_{f 3}^{i} \times \ldots \times C_{f n}^{i}\right)^{1 / n}
$$

where, $P L I=$ pollution load index, $C_{f}^{i}=$ single heavy metal contamination factor.

\subsubsection{Total Load of Extractable Metals (TLM)}

The total load of extractable metals (TLM) in soil was calculated for each site as follows (Simona et al., 2004):

$$
T L M_{j}=\frac{C d_{m}}{C d_{\max }}+\frac{C r_{m}}{C r_{\max }}+\frac{C u_{m}}{C u_{\max }}+\frac{P b_{m}}{P b_{\max }}+\frac{N i_{m}}{N i_{\max }}+\frac{Z n_{m}}{Z n_{\max }}
$$

where, $T L M_{j}=$ total load of extractable metals measured in the jth site, $X_{m}=$ measured value of the heavy metal $X$ at each $j$ th site, $\mathrm{X}_{\max }=$ maximum value of the element $\mathrm{X}$ measured in the $\mathrm{n}_{\mathrm{s}}$ sites, $\mathrm{n}_{\mathrm{s}}=$ number of compared sites.

\subsubsection{Geo-accumulation Index $\left(I_{\text {geo }}\right)$}

Geo-accumulation index $\left(I_{\text {geo }}\right)$ is considered an effective tool to characterize the level of pollution from soil from the hazardous element (Proshad et al., 2018). $I_{\text {geo }}$ was originally introduced and defined by Muller (1969). Geo-accumulation index $\left(I_{g e o}\right)$ can be determined by the following equation:

$I_{\text {geo }}=\mathrm{C}_{\mathrm{n}} /\left(1.5 \times \mathrm{B}_{\mathrm{n}}\right)$

where, $I_{\text {geo }}=$ geo-accumulation index, $\mathrm{C}_{\mathrm{n}}=$ measured concentration of metal $n$ in the soil, $B_{n}=$ geochemical background value of the element in the background sample. Factor 1.5 is introduced to minimize the possible variations in the background values which may be attributed to lithogenic effects (Yu et al., 2012). The interpretation of geo-accumulation index $\left(I_{\text {geo }}\right)$ values is shown in Table 3.

\subsubsection{Ecophysiological indices}

Stress in the microbial population can be determined by the microbial quotient ( $q \mathrm{Mic}$ ) and metabolic quotient $\left(q \mathrm{CO}_{2}\right)$. Organic carbons in soil generally undergo microbial synthesis and are converted to humus. But, in the case of increased stress, more $\mathrm{CO}_{2}$-carbon per unit microbial biomass per unit time is produced to counter stress.

\subsubsection{Metabolic Quotient ( $q \mathrm{CO}_{2}$ )}

The metabolic quotient $\left(q \mathrm{CO}_{2}\right)$ was calculated from basal respiration at the end of the 30 days' incubation period according to the following equation (Anderson and Domsch, 1990).

$$
q \mathrm{CO}_{2}=\frac{\mathrm{r}}{\mathrm{MBC}}
$$

where, $\mathrm{r}=$ respiration rate, $\mathrm{mg} \mathrm{CO}_{2}-\mathrm{C}$ day $^{-1} \mathrm{~g}^{-1}$ soil, $\mathrm{MBC}=$ soil microbial biomass carbon, $\mathrm{mg} \mathrm{C} \mathrm{g}^{-1}$ soil. 


\subsubsection{Microbial Quotient (qMic)}

The microbial quotient ( $q$ Mic) representing the ratio of soil MBC to organic carbon expressed as percent (\%) to explore the percent of organic carbon present as microbial biomass carbon (Anderson and Domsch, 1989):

$q \mathrm{MIC}=\frac{\mathrm{MBC}}{\mathrm{OC}}$

where, $q$ Mic = microbial quotient, $\mathrm{MBC}=$ soil microbial biomass carbon, $\mu \mathrm{g}, \mathrm{OC}=$ total organic carbon, $\mu \mathrm{g}$.

\subsubsection{Ecological model for soil enzyme activity $\left(\mathrm{ED}_{50}\right)$}

The inhibition of enzymatic activity by heavy metal was assessed by two kinetic models (Model 1: Equation 8 and Model 2: Equation 9) and a sigmoidal dose-response model (Model 3: Equation 10) using potential ecological risk index (PER) (Gao et al., 2010). The $50 \%$ ecological dose $\left(\mathrm{ED}_{50}\right)$ values are calculated for Models 1 and 2 by fitting Equation 11 and for Model 3 by fitting the Equation 12:

Model 1: $\mathrm{v}=\frac{c}{1+b P E R}$

Model 2: $\mathrm{v}=\frac{c(1+a P E R)}{1+b P E R}$

Model 3: v $=\frac{x}{1+e^{y(l-z)}}$

$\mathrm{ED}_{50}=\frac{1}{b}$

$\mathrm{ED}_{50}=e^{c}$

where, $\mathrm{ED}_{50}=$ total ecological toxicity coefficients which lead to enzyme activity inhibited by $50 \%, P E R=$ potential ecological risk index under multiple heavy metal pollution in Equation 2, $\mathrm{v}=$ response variable, $\mathrm{a}, \mathrm{b}$ and $\mathrm{c}=$ fitting parameters with positive values and $\mathrm{b}>\mathrm{a}, \mathrm{l}=$ natural logarithm of $P E R, \mathrm{x}=$ uninhibited value of $\mathrm{v}, \mathrm{y}=$ slope factor, $\mathrm{z}=$ natural logarithm of $\mathrm{ED}_{50}$.

\subsubsection{Statistical analyses}

All the measurements were made in triplicate soil samples and the results are expressed on an oven-dry weight basis. Correlations between the selected parameters, level of significance and standard deviation were determined using statistical packages in Office 2016 Program. The effects of different heavy metals were determined by one-way analysis of variance (ANOVA) with three replicates and the significance of the parameters was tested using the least significant difference multiple range test at $p \leq 0.05$ after one-way ANOVA. Pearson's correlation coefficient analyses were carried out with IBM SPSS (version 20.0, Chicago, USA) to study relationships between soil physicochemical properties, heavy metal contents, soil microbial activities and enzyme activities. Pared-samples T-test measured for soil samples firstly by considering soil samples all together $(n=56)$, secondly by considering mean values representing the sites with different activities ( $n=19)$ and thirdly considering site-specific field types $(n=4)$. Regression between soil parameters and soil microbial activities and enzyme activities was fitted to linear and exponential functions. The Principal Component Analysis (PCA) and Agglomerative Hierarchical Clustering (AHC) were performed by XLSTAT.

\section{Results and discussion}

\subsection{Heavy metal contents of the soils}

Heavy metal concentrations in the agricultural soil samples of different land-use sites showed significant variability ranged from 1.77 to $8.10 \mathrm{mg} \cdot \mathrm{kg}^{-1} \mathrm{Cd}, 102.75$ to $262.00 \mathrm{mg} \cdot \mathrm{kg}^{-1} \mathrm{Cr}, 90.52$ to $662.33 \mathrm{mg} \cdot \mathrm{kg}^{-1} \mathrm{Cu}, 26.66$ to $227.47 \mathrm{mg} \cdot \mathrm{kg}^{-1} \mathrm{Ni}, 148.33$ to 1483.33 $\mathrm{mg} \cdot \mathrm{kg}^{-1} \mathrm{~Pb}$ and 270.37 to $1416.13 \mathrm{mg} \cdot \mathrm{kg}^{-1} \mathrm{Zn}$ (Table 4). Heavy metal concentrations in the study region were also compared to the standard values for agricultural soil. As Bangladesh does not have any soil standards for heavy metals, standards developed in China (Chinese Environmental Quality Standards for Soil (Act No. 220/2004 Coll. of Laws) for agricultural soil were used to determine the extent of heavy metal contamination (Table 1). The values of heavy metals in the reference site were within the standard values. Compared with the standard values for agricultural soils, more than $50 \%$ of the mean values of the heavy metals especially $\mathrm{Cd}$ and $\mathrm{Zn}$ were above the standard values in the vegetable garden and vegetable field soils. The mean values of heavy metal contents in soils follow in decreasing order as $\mathrm{Pb}>\mathrm{Zn}>\mathrm{Cd}>\mathrm{Cu}>\mathrm{Cr}>\mathrm{Ni}$. The degree of heavy metal contamination among sampling sites generally followed the order: acid-leaching site $>$ burning site $>$ dismantling site $>$ metal workshop $>$ scrap dumping site $>$ waste oil processing site $>$ electric waste dumping site $>$ burnt plastic dump site $>$ product storage site. The heavy metal concentration of the soil samples collected from the contaminated sites showed consistency between the sites about the heavy metal concentrations. The sites that have higher concentrations have all the heavy metals in high concentrations.

To evaluate the data on heavy metal concentration, the descriptive statistics were calculated (Table 4). The skewness values for $\mathrm{Cr}$ was low and negative $(-0.26)$, however, those for $\mathrm{Cd}, \mathrm{Cu}, \mathrm{Ni}, \mathrm{Pb}$ and $\mathrm{Zn}$ were positively skewed with skewness values of $0.94,1.04,0.86,1.11$, and 0.71 , respectively, indicating non-normality of the data set for these heavy metals. The calculated coefficient of variation (CV) varied from $34.31 \%$ to $75.01 \%$, indicating moderate variation, expressing heterogeneous occurrence (Zhou et al., 2016). It also indicates that the sources of heavy metal were not natural, the sources were anthropogenic. As the workshops of the ship dismantling activities were not structured or planned around the village so there was no uniform distribution of the heavy metals in the area. Concentrations of $\mathrm{Cd}, \mathrm{Cr}, \mathrm{Cu}, \mathrm{Ni}, \mathrm{Pb}$ and $\mathrm{Zn}$ in the present study were also compared to other studies conducted in Bangladesh (Table 1). All the investigated heavy metal concentrations were higher than other studies with agricultural and urban soils of 
Table 4

Descriptive statistics of heavy metals $(\mathrm{Cd}=\mathrm{Cadmium}, \mathrm{Cr}=$ Chromium, $\mathrm{Cu}=\mathrm{Cupper}, \mathrm{Ni}=$ Nickel, $\mathrm{Pb}=\mathrm{Lead}, \mathrm{Zn}=\mathrm{Zinc})$ concentration $(\mathrm{mean}$ \pm SD) in soils of different agricultural soils besides ship scrap processing sites, Sitakunda, Chattogram

\begin{tabular}{|c|c|c|c|c|c|c|}
\hline \multirow[t]{2}{*}{ Descriptive statistics } & $\mathrm{Cd}$ & $\mathrm{Cr}$ & $\mathrm{Cu}$ & $\mathrm{Ni}$ & $\mathrm{Pb}$ & $\mathrm{Zn}$ \\
\hline & \multicolumn{6}{|c|}{$\mathrm{mg} \cdot \mathrm{kg}^{-1}$} \\
\hline \multicolumn{7}{|l|}{ Vegetable garden site } \\
\hline VG1 & $8.10 \pm 0.01^{\text {a }}$ & $262.00 \pm 8.87^{a}$ & $662.33 \pm 6.24^{\mathrm{a}}$ & $227.47 \pm 8.15^{\mathrm{a}}$ & $1483.33 \pm 76.38^{\text {a }}$ & $1416.13 \pm 3.96^{\mathrm{a}}$ \\
\hline VG2 & $7.48 \pm 0.05^{b}$ & $240.37 \pm 1.27^{b}$ & $505.74 \pm 12.97^{b}$ & $192.00 \pm 12.56^{b}$ & $1109.00 \pm 8.54^{\mathrm{b}}$ & $966.07 \pm 23.79^{b}$ \\
\hline VG3 & $5.34 \pm 0.03^{c}$ & $225.89 \pm 1.83^{c}$ & $457.05 \pm 28.48^{c}$ & $162.89 \pm 4.34^{\mathrm{c}}$ & $1106.37 \pm 5.52^{b}$ & $926.49 \pm 22.95^{c}$ \\
\hline VG4 & $1.93 \pm 0.01^{p}$ & $107.01 \pm 1.11^{\mathrm{m}}$ & $94.83 \pm 3.72^{\circ}$ & $28.73 \pm 1.47^{n}$ & $158.47 \pm 2.01^{1}$ & $294.60 \pm 7.83^{n}$ \\
\hline VG5 & $4.60 \pm 0.03^{\mathrm{e}}$ & $191.47 \pm 0.54^{d}$ & $347.73 \pm 2.70^{\mathrm{e}}$ & $141.56 \pm 6.99 \mathrm{e}$ & $716.66 \pm 19.07^{\mathrm{d}}$ & $777.78 \pm 10.18^{\mathrm{e}}$ \\
\hline VG6 & $2.78 \pm 0.02^{\mathrm{k}}$ & $145.15 \pm 2.64^{\mathrm{i}}$ & $144.73 \pm 1.79^{k}$ & $47.60 \pm 3.70^{\mathrm{k}}$ & $352.94 \pm 33.91^{\mathrm{h}}$ & $533.57 \pm 7.55^{j}$ \\
\hline VG7 & $4.10 \pm 0.01^{g}$ & $177.71 \pm 2.16^{\mathrm{e}}$ & $275.16 \pm 1.12^{g}$ & $100.06 \pm 1.64 \mathrm{~g}$ & $560.24 \pm 2.44^{\mathrm{e}}$ & $691.75 \pm 49.11^{\mathrm{f}}$ \\
\hline VG8 & $3.18 \pm 0.01^{\mathrm{i}}$ & $164.54 \pm 1.34^{\mathrm{g}}$ & $201.59 \pm 11.10^{\mathrm{i}}$ & $74.89 \pm 3.89^{i}$ & $432.03 \pm 1.06^{g}$ & $603.37 \pm 5.34^{\mathrm{hi}}$ \\
\hline Minimum & 1.92 & 105.77 & 91.34 & 27.67 & 156.17 & 286.01 \\
\hline Maximum & 8.11 & 268.90 & 668.59 & 236.65 & 1550.00 & 1420.16 \\
\hline Arithmetic mean & $4.69^{\mathrm{x}}$ & $189.27^{x}$ & $336.15^{\mathrm{x}}$ & $121.90^{\mathrm{x}}$ & $739.88^{x}$ & $776.22^{x}$ \\
\hline Median & 4.34 & 185.24 & 310.55 & 117.96 & 629.17 & 745.80 \\
\hline SD & 2.10 & 49.48 & 186.75 & 67.79 & 433.93 & 322.72 \\
\hline CV\% & 44.74 & 26.14 & 55.56 & 55.61 & 58.65 & 41.58 \\
\hline \multicolumn{7}{|l|}{ Vegetable field site } \\
\hline VF1 & $3.46 \pm 0.06^{\mathrm{h}}$ & $169.92 \pm 0.80^{\mathrm{f}}$ & $241.29 \pm 22.51^{\mathrm{h}}$ & $87.66 \pm 3.09^{\mathrm{h}}$ & $513.99 \pm 19.93^{f}$ & $620.13 \pm 3.54^{\mathrm{h}}$ \\
\hline VF2 & $2.84 \pm 0.03^{j}$ & $154.96 \pm 1.60^{h}$ & $165.24 \pm 4.80^{j}$ & $58.26 \pm 1.79$ & $353.89 \pm 7.02^{h}$ & $584.52 \pm 21.44^{\mathrm{i}}$ \\
\hline VF3 & $4.25 \pm 0.05^{\mathrm{f}}$ & $182.23 \pm 4.57^{\mathrm{e}}$ & $313.60 \pm 3.74^{\mathrm{f}}$ & $128.59 \pm 6.26^{f}$ & $551.61 \pm 63.52^{\text {ef }}$ & $660.16 \pm 29.67^{g}$ \\
\hline VF4 & $2.64 \pm 0.02^{1}$ & $141.50 \pm 0.50^{\mathrm{i}}$ & $133.97 \pm 1.84^{\mathrm{kl}}$ & $40.76 \pm 0.85^{\mathrm{kl}}$ & $317.76 \pm 2.32^{\mathrm{hi}}$ & $517.44 \pm 6.82^{j \mathrm{k}}$ \\
\hline VF5 & $2.37 \pm 0.02^{\mathrm{m}}$ & $135.83 \pm 1.56^{j}$ & $127.90 \pm 2.53^{\mathrm{lm}}$ & $37.80 \pm 0.45^{\mathrm{lm}}$ & $285.59 \pm 1.73^{\mathrm{ij}}$ & $501.98 \pm 1.82^{k}$ \\
\hline VF6 & $2.25 \pm 0.02^{n}$ & $123.79 \pm 1.29 \mathrm{kl}$ & $106.87 \pm 4.21^{\text {no }}$ & $32.54 \pm 0.54 \mathrm{mn}$ & $230.40 \pm 2.64^{\mathrm{k}}$ & $414.63 \pm 15.60^{1}$ \\
\hline Minimum & 2.22 & 122.30 & 102.86 & 32.03 & 227.50 & 396.62 \\
\hline Maximum & 4.30 & 187.47 & 317.46 & 134.45 & 624.05 & 679.45 \\
\hline Arithmetic mean & $2.97^{\mathrm{y}}$ & $151.37^{\mathrm{xy}}$ & $181.47^{\mathrm{y}}$ & $64.27^{\mathrm{y}}$ & $375.54^{y}$ & $549.81^{x y}$ \\
\hline Median & 2.74 & 147.85 & 149.25 & 48.74 & 334.76 & 541.94 \\
\hline SD & 0.72 & 20.70 & 75.58 & 35.19 & 123.29 & 85.10 \\
\hline CV\% & 24.11 & 13.67 & 41.65 & 54.75 & 32.83 & 15.48 \\
\hline \multicolumn{7}{|l|}{ Paddy field site } \\
\hline P1 & $2.28 \pm 0.02^{\mathrm{n}}$ & $128.00 \pm 1.00^{\mathrm{k}}$ & $113.01 \pm 2.06^{\mathrm{mn}}$ & $34.38 \pm 2.28^{\mathrm{Imn}}$ & $252.33 \pm 18.50^{\mathrm{jk}}$ & $490.73 \pm 4.95^{\mathrm{k}}$ \\
\hline P2 & $2.12 \pm 0.03^{\circ}$ & $121.00 \pm 2.00^{1}$ & $99.78 \pm 0.55^{\text {no }}$ & $30.83 \pm 0.29 \mathrm{mn}$ & $222.72 \pm 4.93^{k}$ & $352.64 \pm 3.53^{m}$ \\
\hline P3 & $4.81 \pm 0.01^{\mathrm{d}}$ & $195.45 \pm 0.87^{d}$ & $387.24 \pm 5.05^{\mathrm{d}}$ & $154.37 \pm 3.33^{d}$ & $880.33 \pm 18.57^{c}$ & $848.90 \pm 19.77^{d}$ \\
\hline P4 & $1.77 \pm 0.02^{q}$ & $102.75 \pm 1.71^{\mathrm{m}}$ & $90.52 \pm 0.71^{\circ}$ & $26.66 \pm 0.67^{n}$ & $148.33 \pm 5.40^{1}$ & $270.37 \pm 12.27^{n}$ \\
\hline Minimum & 1.75 & 101.26 & 90.05 & 26.00 & 143.25 & 258.13 \\
\hline Maximum & 4.82 & 196.36 & 392.77 & 157.11 & 900.00 & 871.55 \\
\hline Arithmetic mean & $2.74^{y}$ & $136.80^{y}$ & $172.64^{y}$ & $61.56^{y}$ & $375.93^{y}$ & $490.66^{y}$ \\
\hline Median & 2.21 & 124.65 & 105.70 & 31.61 & 228.40 & 422.03 \\
\hline SD & 1.26 & 36.68 & 129.70 & 56.07 & 306.95 & 231.38 \\
\hline CV\% & 46.03 & 26.81 & 75.13 & 91.08 & 81.65 & 47.16 \\
\hline \multicolumn{7}{|l|}{ Reference site } \\
\hline \multirow{3}{*}{ C } & 0.28 & 23.45 & 23.75 & 25.67 & 8.35 & 22.67 \\
\hline & 0.27 & 17.69 & 23.17 & 27.67 & 10.00 & 23.87 \\
\hline & 0.27 & 25.14 & 20.00 & 26.00 & 9.75 & 23.73 \\
\hline Minimum & 0.27 & 17.69 & 20.00 & 25.67 & 8.35 & 22.67 \\
\hline Maximum & 0.28 & 25.14 & 23.75 & 27.67 & 10.00 & 23.87 \\
\hline Arithmetic mean & $0.27^{z}$ & $22.09^{z}$ & $22.31^{z}$ & $26.44^{y}$ & $9.37^{z}$ & $23.42^{2}$ \\
\hline Median & 0.27 & 23.45 & 23.17 & 26.00 & 9.75 & 23.73 \\
\hline SD & 0.01 & 3.91 & 2.02 & 1.07 & 0.89 & 0.66 \\
\hline CV\% & 2.20 & 17.68 & 9.05 & 4.05 & 9.49 & 2.81 \\
\hline \multicolumn{7}{|c|}{ 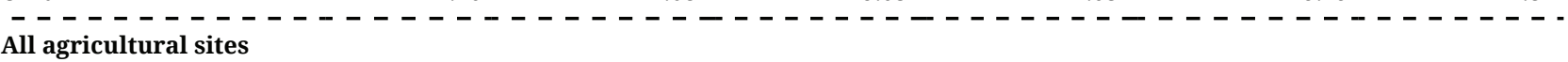 } \\
\hline Range & 7.84 & 251.21 & 648.59 & 210.98 & 1541.65 & 1397.49 \\
\hline Minimum & 0.27 & 17.69 & 20.00 & 25.67 & 8.35 & 22.67 \\
\hline Maximum & 8.11 & 268.90 & 668.59 & 236.65 & 1550.00 & 1420.16 \\
\hline \multicolumn{7}{|l|}{ Mean } \\
\hline Statistic & 3.50 & 157.46 & 236.36 & 85.97 & 509.76 & 604.98 \\
\hline Std. Error & 0.25 & 7.16 & 22.13 & 8.27 & 50.64 & 39.73 \\
\hline Std. Deviation & 1.91 & 54.03 & 167.10 & 62.47 & 382.35 & 299.92 \\
\hline \multicolumn{7}{|l|}{ Skewness } \\
\hline Statistic & 0.94 & -0.26 & 1.04 & 0.86 & 1.11 & 0.71 \\
\hline Std. Error & 0.32 & 0.32 & 0.32 & 0.32 & 0.32 & 0.32 \\
\hline \multicolumn{7}{|l|}{ Kurtosis } \\
\hline Statistic & 0.62 & 0.70 & 0.33 & -0.49 & 0.50 & 1.31 \\
\hline Std. Error & 0.62 & 0.62 & 0.62 & 0.62 & 0.62 & 0.62 \\
\hline
\end{tabular}

Each mean is the average of the values obtained for three samples of each soil. Values in the same column followed by the same letter(s) are not significantly different at $p<0.05$ according to ANOVA. x,y,z for variation in land use types. Sampling sites legend description in Table 2. 
Chattogram (Hasan et al., 2020) but consistent with the heavy metal content of sediments of shipyards (Alam et al., 2019; Rahman et al., 2019a; Chowdhury and Rasid, 2016).

The acid-leaching site and burning site of both vegetable garden and field soils showed a relatively high concentration of $\mathrm{Cr}$ and $\mathrm{Ni}$ compared to other sites. The elevated levels of $\mathrm{Cr}$ and Ni may be resulted from waste residues from acid leaching, burning and dismantling sites. Alarmingly, the concentrations of $\mathrm{Cu}$ in all the sampling sites were 2-13 times higher than the standard limit. The concentration of $\mathrm{Cu}$ in sample VG1 (662.33 $\mathrm{mg} \cdot \mathrm{kg}^{-1}$ ), collected from the vegetable garden nearby an acid leaching workshop, was the highest detected concentration in the agricultural field soils. The exception was $\mathrm{Pb}$, for which the concentration was high and above the standard level in all the sites other than the burnt plastic zone in VG, e-waste zone in VF and paddy field and storage site near paddy fields. In general, there were highly significant $(0.92$ to $0.99 \%, p<0.05)$ positive significant linear relation between various pairs of metals, reflecting their simultaneous release of an identical source or activity from the shipyard zone, transport and accumulation in soil (Ali et al., 2016). Differences in the recycling activities in each site may influence the distribution patterns of these metal pollutants.

A disproportionally high concentration of all the heavy metals in burning and acid-leaching sites indicates that point source pollutions existed in the sampling area. Irrigation can be a major pathway because the paddy and vegetable fields were irrigated with this untreated pond water and wastewater which was contaminated with different forms of $\mathrm{Cr}, \mathrm{Pb}$, Ni and $\mathrm{Zn}$. Running off of acid rainwater from burning site (VG2, VF1), burnt plastic dump site (VG4), electric waste dumping site (VG6, VF6, P2), scrap dumping site (P1) carrying different levels of heavy metals can also be a source of heavy metal to the vegetable field and paddy field. Toxic heavy metals $\mathrm{Pb}, \mathrm{Ni}, \mathrm{Cd}$, and $\mathrm{Cr}$ of sulfates, nitrates and chlorides are present in rainwater. E-waste contains $\mathrm{Cd}, \mathrm{Cu}, \mathrm{Cr}$ and $\mathrm{Ni}$ (Adesokan et al., 2016) because waste segregation is not common in Bangladesh. The workshop dust seems to carry the most serious toxic metals, followed by the open burning site soil and the dumpsite soil. Anoxic conditions in the paddy soil during the flooded period can esteem the formation of insoluble cadmium sulfide (Adesokan et al., 2016) and dissolution of Fe-Mn oxyhydroxides by releasing of adsorbed metals such as $\mathrm{Pb}$ and $\mathrm{Zn}$ (Rieuwerts et al., 1998). This could also explain why $\mathrm{Cd}$ and $\mathrm{Zn}$ accumulated in the paddy soil. The content of heavy metal may increase with operation time. Heavy metal concentration in some agricultural sites with similar activities (acid leaching, burning, dismantling and metal workshop) can be varied due to workshop operation time and structure. Brick structured workshops designed for scrap metal processing caused less heavy metal emission than unstructured open metal workshops. The agricultural soils beside the workshops along the Dhaka- Chattogram highway which run for decades were polluted more seriously.

\subsubsection{Ecological risk assessment of heavy metals in the study area}

The PER which shows the extent of contamination of the sampling sites indicated very high contamination of all the sampling sites. However, no potential ecological risk was found with reference sites, for which the sum of toxic units was lower than 40. In most soil samples, the $E_{r}^{i}$ factors of Cd ranged above 160, and contamination levels were high risk to very high risk. The $C_{d}$ and $P L I$ followed a similar pattern of contamination result as for $P E R$ and suggest that agricultural soils in the area under investigation were very highly polluted with heavy metals (Fig. 2). Regarding the PER, VG1 and VG2 sites were moderate to considerably under risk with $\mathrm{Ni}$ and $\mathrm{Zn}$. The ecological risk of $\mathrm{Pb}$ in the burning and acid-leaching sites was very high and $\mathrm{Cu}$ was at a considerable level. Among the land uses statistically significant differences $(p<0.05)$ were observed for the PER of heavy metal, which indicated that the combined ecological risk of heavy metals can vary with the impact of scrap processing activities along with different land uses (Table 5). The PER of the environment for the different types of land use can be ranked in the following order: vegetable garden> vegetable field $>$ paddy field $>$ reference site.

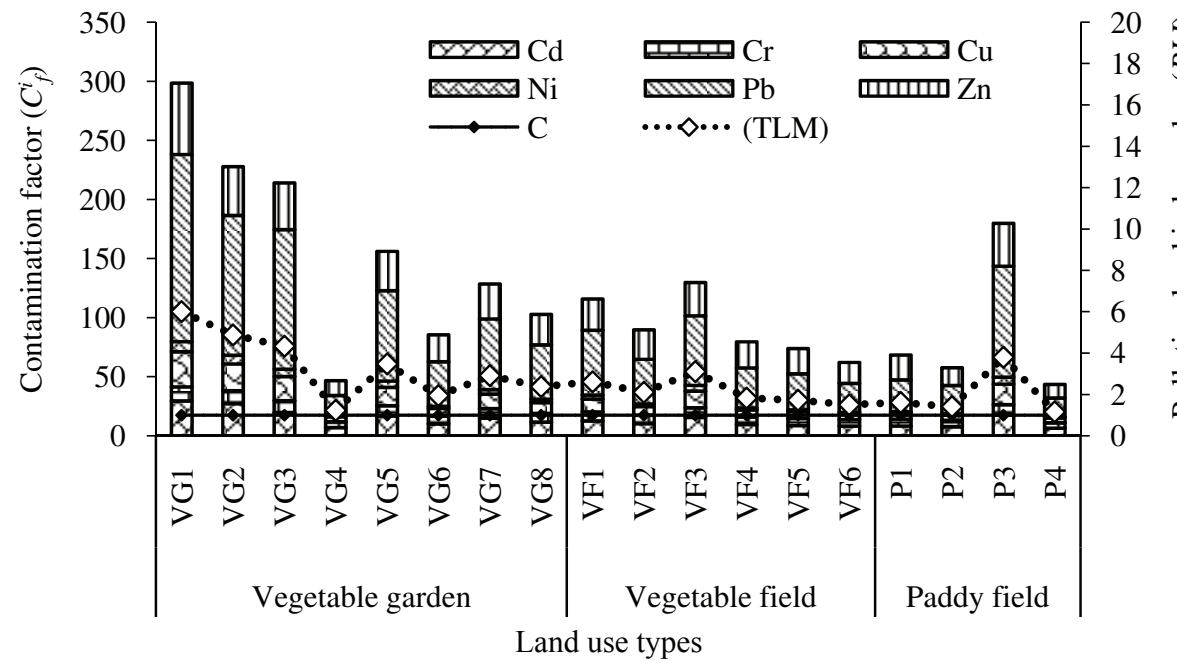

Land use types
Fig. 2. Contamination factor $\left(C^{i}\right)$, degree of Contamination $\left(C_{d}\right)$ and pollution load index $(P L I)$ value of heavy metals (Cd = Cadmium, $\mathrm{Cr}=$ Chromium, $\mathrm{Cu}=\mathrm{Cup}-$ per, $\mathrm{Ni}=$ Nickel, $\mathrm{Pb}=$ Lead, $\mathrm{Zn}=\mathrm{Zinc}$ ) in different agricultural soils besides ship scrap processing sites, Sitakunda, Chattogram. Sampling sites legend description in Table 2 
Table 5

Potential ecological risk factor $\left(E_{r}^{i}\right)$, potential ecological risk index $(P E R)$ and pollution degree of heavy metals in different agricultural soils besides ship scrap processing sites, Sitakunda, Chattogram

\begin{tabular}{|c|c|c|c|c|c|c|c|c|}
\hline \multirow{2}{*}{$\begin{array}{l}\text { Sampling } \\
\text { sites }\end{array}$} & \multicolumn{6}{|c|}{ Potential ecological risk factor $\left(\mathrm{E}_{\mathrm{r}}^{\mathrm{i}}\right)$} & \multirow{2}{*}{$\begin{array}{c}\text { Potential } \\
\text { ecological risk }\end{array}$} & \multirow{2}{*}{$\begin{array}{c}\text { Pollution } \\
\text { degree }\end{array}$} \\
\hline & $\mathrm{Cd}$ & $\mathrm{Cr}$ & $\mathrm{Cu}$ & $\mathrm{Ni}$ & $\mathrm{Pb}$ & $\mathrm{Zn}$ & & \\
\hline VG1 & $888.82^{\mathrm{a}}$ & $23.72^{\mathrm{a}}$ & $148.47^{\mathrm{a}}$ & $51.61^{\mathrm{a}}$ & $791.81^{a}$ & $60.46^{\mathrm{a}}$ & $1964.89^{\mathrm{a}}$ & Very high \\
\hline VG2 & $820.29^{b}$ & $21.76^{\mathrm{b}}$ & $113.37^{b}$ & $43.56^{\mathrm{b}}$ & $591.99^{b}$ & $41.25^{\mathrm{b}}$ & $1632.22^{b}$ & Very high \\
\hline VG3 & $585.81^{\mathrm{c}}$ & $20.45^{c}$ & $102.45^{c}$ & $36.96^{c}$ & $590.59^{b}$ & $39.56^{c}$ & $1375.81^{\mathrm{c}}$ & Very high \\
\hline VG4 & $211.50^{\mathrm{p}}$ & $9.69^{\mathrm{m}}$ & $21.26^{\circ}$ & $6.52^{\mathrm{n}}$ & $84.59^{1}$ & $12.58^{\mathrm{n}}$ & $346.13^{n}$ & Very high \\
\hline VG5 & $504.27^{\mathrm{e}}$ & $17.33^{\mathrm{d}}$ & $77.95^{\mathrm{e}}$ & $32.12^{\mathrm{e}}$ & $382.56^{\mathrm{d}}$ & $33.21^{\mathrm{e}}$ & $1047.43^{e}$ & Very high \\
\hline VG6 & $305.45^{\mathrm{k}}$ & $13.14^{\mathrm{i}}$ & $32.44^{\mathrm{k}}$ & $10.80^{\mathrm{k}}$ & $188.40^{\mathrm{h}}$ & $22.78^{j}$ & $573.01^{\mathrm{i}}$ & Very high \\
\hline VG7 & $449.76^{\mathrm{g}}$ & $16.09^{\mathrm{e}}$ & $61.68^{\mathrm{g}}$ & $22.70^{\mathrm{g}}$ & $299.06^{\mathrm{e}}$ & $29.53^{f}$ & $878.83^{f}$ & Very high \\
\hline VG8 & $348.98^{i}$ & $14.89^{g}$ & $45.19^{\mathrm{i}}$ & $16.99^{i}$ & $230.62^{\mathrm{g}}$ & $25.76 \mathrm{~h}^{\mathrm{i}}$ & $682.44^{\mathrm{h}}$ & Very high \\
\hline VF1 & $379.21^{\mathrm{h}}$ & $15.38^{\mathrm{f}}$ & $54.09^{\mathrm{h}}$ & $19.89^{\mathrm{h}}$ & $274.37^{\mathrm{f}}$ & $26.48^{\mathrm{h}}$ & $769.41^{\mathrm{g}}$ & Very high \\
\hline VF2 & $311.56^{j}$ & $14.03^{\mathrm{h}}$ & $37.04^{\mathrm{j}}$ & $13.22^{j}$ & $188.91^{\mathrm{h}}$ & $24.96^{\mathrm{i}}$ & $589.71^{\mathrm{i}}$ & Very high \\
\hline VF3 & $466.51^{\mathrm{f}}$ & $16.50^{\mathrm{e}}$ & $70.30^{\mathrm{f}}$ & $29.18^{\mathrm{f}}$ & $294.45^{\mathrm{ef}}$ & $28.19^{g}$ & $905.11^{\mathrm{f}}$ & Very high \\
\hline VF4 & $289.25^{1}$ & $12.81^{\mathrm{i}}$ & $30.03^{\mathrm{kl}}$ & $9.25^{\mathrm{kl}}$ & $169.62^{\mathrm{hi}}$ & $22.09^{j \mathrm{k}}$ & $533.05^{j}$ & Very high \\
\hline VF5 & $259.88^{\mathrm{m}}$ & $12.30^{\mathrm{j}}$ & $28.67^{\mathrm{lm}}$ & $8.58^{\mathrm{lm}}$ & $152.45^{\mathrm{ij}}$ & $21.43^{\mathrm{k}}$ & $483.30^{\mathrm{k}}$ & Very high \\
\hline VF6 & $246.47^{n}$ & $11.21 \mathrm{k}^{1}$ & $23.96^{\text {no }}$ & $7.38^{\mathrm{mn}}$ & $122.99^{k}$ & $17.70^{1}$ & $429.70^{1 \mathrm{~m}}$ & Very high \\
\hline $\mathrm{P} 1$ & $250.12^{\mathrm{n}}$ & $11.59^{\mathrm{k}}$ & $25.33^{\mathrm{mn}}$ & $7.80 \mathrm{l}^{\mathrm{mn}}$ & $134.70^{j \mathrm{k}}$ & $20.95^{k}$ & $450.49^{1}$ & Very high \\
\hline $\mathrm{P} 2$ & $232.04^{\circ}$ & $10.95^{1}$ & $22.37^{\text {no }}$ & $6.99^{\mathrm{mn}}$ & $118.89^{k}$ & $15.06^{\mathrm{m}}$ & $406.30^{\mathrm{m}}$ & Very high \\
\hline P3 & $528.04^{\mathrm{d}}$ & $17.69^{d}$ & $86.80^{\mathrm{d}}$ & $35.03^{d}$ & $469.93^{c}$ & $36.24^{\mathrm{d}}$ & $1173.73^{\mathrm{d}}$ & Very high \\
\hline P4 & $193.84^{q}$ & $9.30^{\mathrm{m}}$ & $20.29^{\circ}$ & $6.05^{n}$ & $79.18^{1}$ & $11.54^{\mathrm{n}}$ & $320.21^{n}$ & Very high \\
\hline C & $30.00^{r}$ & $2.00^{\mathrm{n}}$ & $5.00^{p}$ & $6.00^{\mathrm{n}}$ & $5.00^{\mathrm{m}}$ & $1.00^{\circ}$ & $49.00^{\circ}$ & Low \\
\hline
\end{tabular}

Vertically letters show statistically significant differences at $(p<0.05)$ among the land uses of each element. Bold indicates very high ecological risk. Sampling sites legend description in Table 2.

\subsubsection{Geo-accumulation Index $\left(I_{g e o}\right)$}

The $I_{\text {geo }}$ is an effective numerical model, which has widely been used to evaluate the heavy metal contamination in agricultural soils (Adimalla and Li, 2019). The classification of $I_{\text {geo }}$ given by Yu et al., (2012) is shown in Table 3 and its distribu-

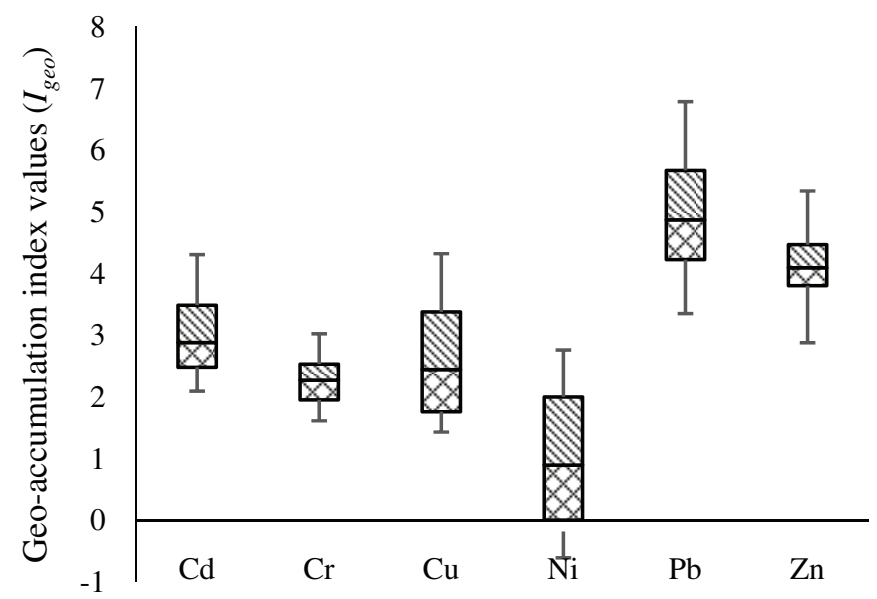

tion is presented in Fig. 3. The $I_{\text {geo }}$ values of all the heavy metals were found higher than 0 around the agricultural soils of the ship scrap processing sites, indicating the moderately to heavily contaminated soils by heavy metals. They indicate the contamination of soils caused by anthropogenic sources. The ranking of $I_{\text {geo }}$ value is $\mathrm{Pb}>\mathrm{Zn}>\mathrm{Cu}>\mathrm{Cr}>\mathrm{Cd}>\mathrm{Ni}$.
Fig. 3. Box and whisker plots display the distribution of the Geo-accumulation index $\left(I_{g e o}\right)$ value of heavy metals $(\mathrm{Cd}=$ Cadmium, $\mathrm{Cr}=$ Chromium, $\mathrm{Cu}=$ Cupper, $\mathrm{Ni}=$ Nickel, $\mathrm{Pb}=$ Lead, $\mathrm{Zn}=$ Zinc) in different agricultural soils besides ship scrap processing sites, Sitakunda, Chattogram (error bar represents \pm SD) 


\subsubsection{Source analysis of heavy metals under the study area}

The PCA was performed to study the relationship between soil heavy metals, heavy metal indices and ship scrap processing sites. The result shows that the first and second principal components (PC1 and PC2) accounted for $57.07 \%$ and $17.57 \%$ of the total variance, respectively (Fig. 4).

The soil heavy metals and heavy metal indices were positively related to the acid leaching, dismantling, burning sites and negatively related reference site implying that the by product of acid leaching and dismantling of ship scrap was one of the major sources for heavy metal contamination. Acid leaching activities increased the heavy metal content in the soil. A high relative similarity was observed between the dismantling site and burning site soil and $\mathrm{Cd}, \mathrm{Cu}, \mathrm{Ni}$ and $\mathrm{Zn}$ and the distribution pattern of $\mathrm{Cd}$ and $\mathrm{Cu}$ were reasonably similar; this may imply that these heavy metals were mainly released from these two sites.

\subsection{Effect of heavy metals on soil microbial number and activity}

Significant variations have been observed in the microbial properties of soils of the studied area. The number of cultivable bacteria and fungi was found to be significantly low in agricultural soils than in reference soil. The number of cultivable bacteria and fungi in agricultural sites varied from $85 \times 10^{5}$ to $448 \times 10^{5}$ CFU. $\mathrm{g}^{-1}$ dry soil and $161 \times 10^{3}$ to $686 \times 10^{3} \mathrm{CFU} \cdot \mathrm{g}^{-1}$ dry soil respectively. SIR, MA and MBC showed significant differences between agricultural sites and reference site. Microbial properties in the agricultural soil samples ranged from 28.49 to $68.45 \mathrm{mg} \mathrm{CO} \cdot \mathrm{g}^{-1}$ for SIR, 10.42 to $32.33 \mathrm{mg} \mathrm{CO}{ }_{2}-\mathrm{C} \cdot \mathrm{g}^{-1}$ day $^{-1}$ for MA and 134.37 to $567.40 \mathrm{mg} \mathrm{C} \cdot \mathrm{kg}^{-1}$ for MBC. The mean of microbial properties in reference site soil was $72.25 \mathrm{mg} \mathrm{CO}_{2} \cdot \mathrm{g}^{-1}$ for SIR, $42.17 \mathrm{mg} \mathrm{CO}_{2}-\mathrm{C} \cdot \mathrm{g}^{-1}$ day $^{-1}$ for MA, $982.67 \mathrm{mg} \mathrm{C} \cdot \mathrm{kg}^{-1}$ for MBC respectively (Table 6 ). The microbial properties were also varied among the sampling sites of different land-use types and followed the descending order of paddy, vegetable field and vegetable garden soils. There were more than $80 \%$ fewer of cultivable bacteria and fungi and MBC in the acid-leaching site, burning site, dismantling site of VG and metal workshop site of paddy field due to ship scrap processing activities related to the reference site. The value of $q$ Mic varied from $0.25-0.81 \%$ in the agricultural soils. The negative effect of shipbreaking activities on soil microbiological properties in the contaminated soils has been revealed from the result as all the microbial parameters were significantly lower than in the reference site soils.

The soil microbial properties of the present study showed strong interrelations among themselves which is visible from Pearson's correlation coefficients (Fig. 5). Microbial population (bacteria and fungi) and SIR, microbial quotients were positively correlated with the MBC in soils and the correlation was significant at $0.05 \%$ level. High correlations between SIR and MBC $(r=0.82)$ indicate microbes highly respond with added glucose i.e. substrate, especially bacteria in the contaminated soils (Fig. 5). Correlations of bacteria with microbial activity $(r=0.88)$ and with $\mathrm{MBC}(\mathrm{r}=0.84$, significant at $0.05 \%$ level) indicate more activeness and greater contribution of bacteria to MBC than fungi in contaminated soils.

Microbial activities found to be decreased in the highly contaminated agricultural soils and significant negative relations were found between soil heavy metal contents and microbial

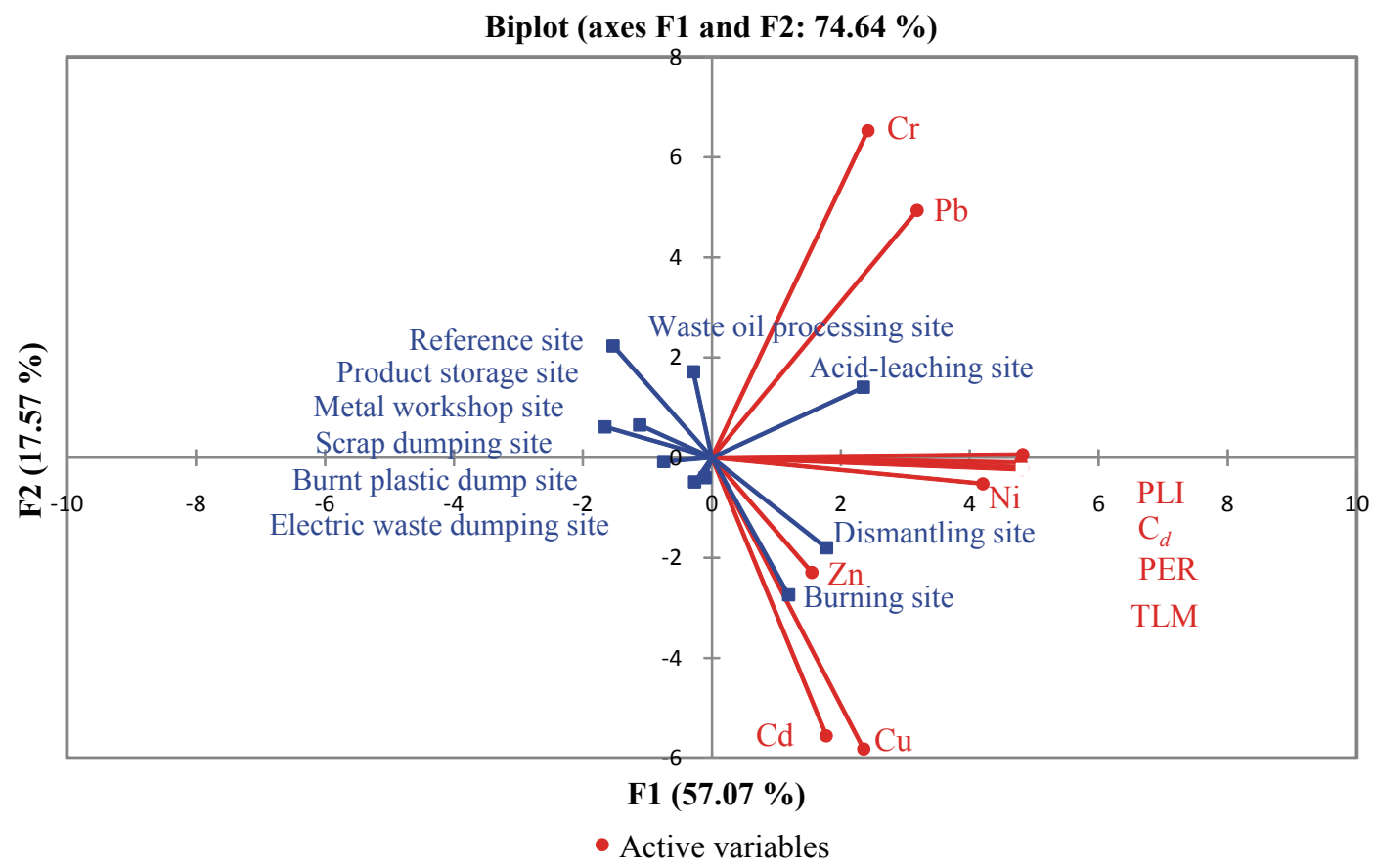

Fig. 4. Principal component analysis (PCA) plot showing the similarity of heavy metal $(\mathrm{Cd}=\mathrm{Cadmium}, \mathrm{Cr}=\mathrm{Chromium}, \mathrm{Cu}=\mathrm{Cupper}$, Ni $=\mathrm{Nickel}$, $\mathrm{Pb}=$ Lead, $\mathrm{Zn}=$ Zinc) concentrations and heavy metal indices $\left(P L I=\right.$ Pollution load index, $\mathrm{C}_{d}=$ Integrated pollution degree, $P E R=$ Potential ecological risk, TLM = Total load of extractable metals) among sampling sites 
Table 6

The number of cultivable bacteria (Bacteria), number of cultivable fungi (Fungi), substrate-induced respiration (SIR), microbial biomass carbon (MBC), mineralization quotient ( $q \mathrm{Mic}$ ) and metabolic quotient $\left(q \mathrm{CO}_{2}\right)$ (mean $\pm \mathrm{SD}$ ) in different agricultural soils besides ship scrap processing sites, Sitakunda, Chattogram

\begin{tabular}{|c|c|c|c|c|c|c|c|}
\hline \multirow[t]{2}{*}{ Legend } & Bacteria & Fungi & SIR & MA & $\mathrm{MBC}$ & $q \mathrm{Mic}$ & $q \mathrm{CO}_{2}$ \\
\hline & $\begin{array}{c}\times 10^{5} \mathrm{CFU} \cdot \mathrm{g}^{-1} \\
\text { dry soil }\end{array}$ & $\begin{array}{c}\times 10^{3} \mathrm{CFU} \cdot \mathrm{g}^{-1} \\
\text { dry soil }\end{array}$ & $\mathrm{mg} \mathrm{CO} \cdot \mathrm{g}^{-1}$ & $\mathrm{mg} \mathrm{CO}_{2}-\mathrm{C} \cdot \mathrm{g}^{-1} \mathrm{day}^{-1}$ & $\mathrm{mg} \mathrm{C} \cdot \mathrm{kg}^{-1}$ & $\%$ & $\begin{array}{l}\mathrm{mg} \mathrm{CO}-\mathrm{C} \cdot \mathrm{mg}^{-1} \\
\mathrm{Cmic} \cdot \mathrm{h}^{-1} \times 10^{-4}\end{array}$ \\
\hline \multicolumn{8}{|l|}{ Vegetable garden } \\
\hline VG1 & $85 \pm 4^{\mathrm{a}}$ & $161 \pm 11^{\mathrm{a}}$ & $28.49 \pm 2.49^{\mathrm{a}}$ & $10.42 \pm 0.38^{\mathrm{a}}$ & $134.37 \pm 5.32^{\mathrm{a}}$ & $0.25 \pm 0.01^{\mathrm{a}}$ & $0.08 \pm 0.01^{\mathrm{a}}$ \\
\hline VG2 & $94 \pm 4^{b}$ & $178 \pm 7^{b}$ & $32.43 \pm 0.99^{b}$ & $11.47 \pm 0.25^{\mathrm{a}}$ & $164.18 \pm 3.39^{b}$ & $0.31 \pm 0.01^{\mathrm{ab}}$ & $0.07 \pm 0.00^{\mathrm{b}}$ \\
\hline VG3 & $102 \pm 1^{c}$ & $191 \pm 2^{b}$ & $37.72 \pm 0.25^{c}$ & $13.03 \pm 0.82^{b}$ & $214.66 \pm 8.09^{c}$ & $0.40 \pm 0.01^{c}$ & $0.06 \pm 0.00^{\mathrm{b}}$ \\
\hline VG4 & $434 \pm 1^{p}$ & $655 \pm 4^{\mathrm{m}}$ & $59.04 \pm 1.57^{m}$ & $24.18 \pm 0.18^{h}$ & $504.36 \pm 4.53^{\mathrm{k}}$ & $0.62 \pm 0.04^{\mathrm{f}}$ & $0.05 \pm 0.00^{\mathrm{g}}$ \\
\hline VG5 & $139 \pm 2^{\mathrm{e}}$ & $243 \pm 10^{d}$ & $40.75 \pm 0.70^{\mathrm{de}}$ & $14.68 \pm 0.29^{c}$ & $246.79 \pm 4.32^{\mathrm{d}}$ & $0.53 \pm 0.00^{\text {de }}$ & $0.06 \pm 0.00^{\mathrm{def}}$ \\
\hline VG6 & $272 \pm 10^{j}$ & $259 \pm 6^{e}$ & $47.56 \pm 0.15^{h}$ & $20.25 \pm 0.54^{\mathrm{ef}}$ & $363.78 \pm 1.69^{\mathrm{fg}}$ & $0.49 \pm 0.00^{\mathrm{d}}$ & $0.06 \pm 0.00^{\mathrm{f}}$ \\
\hline VG7 & $155 \pm 2^{\mathrm{f}}$ & $272 \pm 3^{e}$ & $43.15 \pm 0.56^{f}$ & $17.08 \pm 0.60^{\mathrm{d}}$ & $291.46 \pm 0.96^{\mathrm{e}}$ & $0.48 \pm 0.00^{\mathrm{d}}$ & $0.06 \pm 0.00^{\mathrm{def}}$ \\
\hline VG8 & $186 \pm 5^{\mathrm{h}}$ & $291 \pm 12^{\mathrm{f}}$ & $45.72 \pm 0.24^{\mathrm{g}}$ & $21.14 \pm 0.49^{f}$ & $376.45 \pm 3.06^{g h}$ & $0.72 \pm 0.00^{\text {ghi }}$ & $0.06 \pm 0.00^{\text {ef }}$ \\
\hline \multicolumn{8}{|l|}{ Vegetable field } \\
\hline VF1 & $176 \pm 11^{g}$ & $323 \pm 13^{g}$ & $45.13 \pm 0.23^{g}$ & $19.77 \pm 0.05^{\mathrm{e}}$ & $354.59 \pm 2.49^{f}$ & $0.69 \pm 0.00^{g h}$ & $0.06 \pm 0.00^{f}$ \\
\hline VF2 & $201 \pm 4^{\mathrm{i}}$ & $509 \pm 7^{h}$ & $46.42 \pm 0.36^{\mathrm{gh}}$ & $22.67 \pm 0.15^{g}$ & $394.29 \pm 1.59^{h}$ & $0.73 \pm 0.00^{\text {ghij }}$ & $0.06 \pm 0.00^{\text {ef }}$ \\
\hline VF3 & $148 \pm 1^{\mathrm{f}}$ & $537 \pm 15^{\mathrm{i}}$ & $42.05 \pm 0.33^{\mathrm{ef}}$ & $24.70 \pm 0.30^{\mathrm{h}}$ & $365.19 \pm 5.99^{\mathrm{fg}}$ & $0.67 \pm 0.11^{\mathrm{fg}}$ & $0.07 \pm 0.00^{\mathrm{bc}}$ \\
\hline VF4 & $307 \pm 2^{1}$ & $583 \pm 9^{j}$ & $48.05 \pm 0.30^{\mathrm{hi}}$ & $27.85 \pm 0.41^{\mathrm{i}}$ & $457.26 \pm 19.78^{j}$ & $0.81 \pm 0.04^{\mathrm{k}}$ & $0.06 \pm 0.00^{\text {def }}$ \\
\hline VF5 & $285 \pm 10^{\mathrm{k}}$ & $606 \pm 6^{\mathrm{k}}$ & $49.57 \pm 0.47^{\mathrm{i}}$ & $27.43 \pm 0.51^{\mathrm{i}}$ & $430.43 \pm 5.10^{\mathrm{i}}$ & $0.75 \pm 0.01^{\mathrm{hij}}$ & $0.06 \pm 0.00^{\mathrm{cd}}$ \\
\hline VF6 & $362 \pm 7^{n}$ & $607 \pm 2^{\mathrm{k}}$ & $51.41 \pm 1.09 j$ & $28.40 \pm 1.15^{\mathrm{i}}$ & $462.66 \pm 5.14^{\mathrm{j}}$ & $0.77 \pm 0.01^{\mathrm{ijk}}$ & $0.06 \pm 0.00^{\mathrm{ed}}$ \\
\hline \multicolumn{8}{|l|}{ Paddy field sites } \\
\hline $\mathrm{P} 1$ & $339 \pm 11^{\mathrm{m}}$ & $684 \pm 9^{n}$ & $53.40 \pm 0.69^{k}$ & $24.00 \pm 0.90^{\mathrm{h}}$ & $413.72 \pm 4.96^{\mathrm{i}}$ & $0.56 \pm 0.02^{\mathrm{e}}$ & $0.06 \pm 0.00^{\text {ef }}$ \\
\hline $\mathrm{P} 2$ & $380 \pm 4^{\circ}$ & $513 \pm 5^{\mathrm{h}}$ & $55.20 \pm 1.14^{1}$ & $32.33 \pm 1.04^{j}$ & $562.98 \pm 5.01^{1}$ & $0.79 \pm 0.01^{\mathrm{jk}}$ & $0.06 \pm 0.00^{e f}$ \\
\hline P3 & $114 \pm 1^{d}$ & $215 \pm 11^{c}$ & $39.28 \pm 0.51^{\mathrm{cd}}$ & $16.67 \pm 1.04^{\mathrm{d}}$ & $221.22 \pm 9.29^{c}$ & $0.34 \pm 0.02^{\mathrm{bc}}$ & $0.08 \pm 0.01^{\mathrm{a}}$ \\
\hline $\mathrm{P} 4$ & $439 \pm 2^{p}$ & $622 \pm 6^{1}$ & $68.45 \pm 0.57^{n}$ & $28.43 \pm 0.60^{\mathrm{i}}$ & $567.40 \pm 40.03^{1}$ & $0.69 \pm 0.05^{g h}$ & $0.05 \pm 0.00^{g}$ \\
\hline \multicolumn{8}{|l|}{ Reference site } \\
\hline C & $448 \pm 0.1^{\mathrm{q}}$ & $686 \pm 4^{n}$ & $72.25 \pm 1.61^{\circ}$ & $42.17 \pm 1.76^{\mathrm{k}}$ & $982.67 \pm 6.00^{\mathrm{m}}$ & $1.12 \pm 0.02^{1}$ & $0.04 \pm 0.00^{\mathrm{h}}$ \\
\hline Vegetable garden & $183 \pm 113^{x}$ & $281 \pm 151^{x}$ & $41.86 \pm 9.12^{\mathrm{x}}$ & $16.53 \pm 4.76^{\mathrm{x}}$ & $287.01 \pm 117.86^{x}$ & $0.47 \pm 0.01^{\mathrm{x}}$ & $0.06 \pm 0.01^{\mathrm{x}}$ \\
\hline Vegetable field & $246 \pm 79^{x y}$ & $527 \pm 101^{y}$ & $47.11 \pm 3.16^{x y}$ & $25.14 \pm 3.24^{y}$ & $410.74 \pm 44.20^{y}$ & $0.74 \pm 0.00^{y}$ & $0.06 \pm 0.00^{x}$ \\
\hline Paddy field & $318 \pm 128^{y}$ & $509 \pm 188^{y}$ & $54.08 \pm 10.81^{y}$ & $25.36 \pm 6.13^{y}$ & $441.33 \pm 148.69^{y}$ & $0.59 \pm 0.01^{x}$ & $0.06 \pm 0.01^{x}$ \\
\hline Reference & $448 \pm 1^{z}$ & $686 \pm 4^{z}$ & $72.25 \pm 1.61^{z}$ & $42.17 \pm 1.76^{z}$ & $982.67 \pm 6.00^{z}$ & $1.12 \pm 0.00^{z}$ & $0.04 \pm 0.00^{y}$ \\
\hline
\end{tabular}

Each mean is the average of the values obtained for three samples of each soil. Values in the same column followed by the same letter(s) are not significantly different at $p<0.05$ according to ANOVA. Sampling sites legend description in Table 2.

number and activities in soils with high heavy metal content (Table 7). The $q$ Mic decreased with increasing the soil heavy metal content. The $q \mathrm{CO}_{2}$ varied widely and showed an increasing trend with the decrease of heavy metal content. The mechanism involved in inactivating and inhibiting soil microbial activity differs for different heavy metals. In our study, soil microbiological properties showed considerable differences relating to different heavy metals; the negative effects from heavy metal to soil microbial properties have been reported, suggesting that soil microbial properties are significantly inhibited by heavy metals (Li et al., 2018). A marked decrease in total cultivable numbers of soil microorganisms for the heavy metal contaminated soil samples indicate that $\mathrm{Pb}, \mathrm{Cd}, \mathrm{Zn}$ and $\mathrm{Cu}$ inhibit soil microbial population (Abdu et al., 2017). Bacteria seem to be more sensitive to heavy metal contamination than fungi (Table 7). According to Liu et al., (2007), the way heavy metals act depends on their type and rate. Lead doses above $50 \mathrm{mg} \cdot \mathrm{kg}^{-1}$ decreased the count of both bacteria and fungi. Khan et al., (2008) showed the inhibitory effect of high $\mathrm{Cd}$ and $\mathrm{Pb}$ concentrations on soil MBC. Heavy metals decrease $\mathrm{MBC}$ and reduce their activity in the soil (Wyszkowska et al., 2008). MBC is a sensitive parameter and can be used as an indicator of changes in OM composition (Yang et al., 2006). The decrease in MBC caused by a high level of heavy metal contamination found at the sites agrees with Wang et al., (2007). The 
a

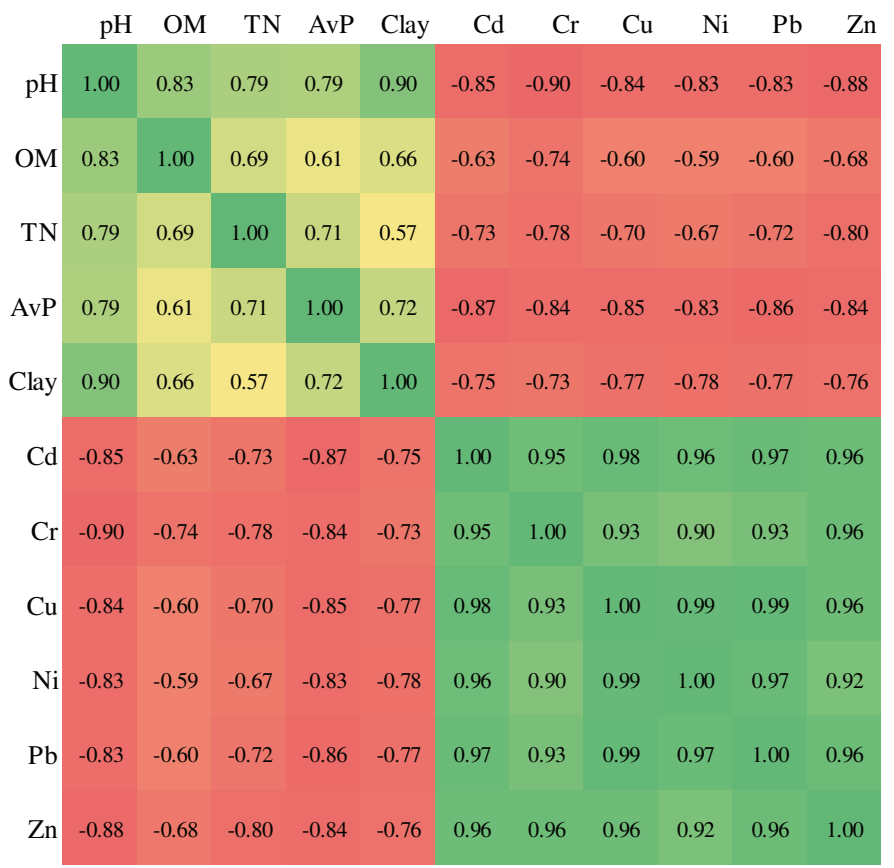

$\mathrm{b}$

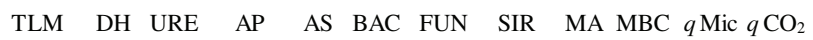

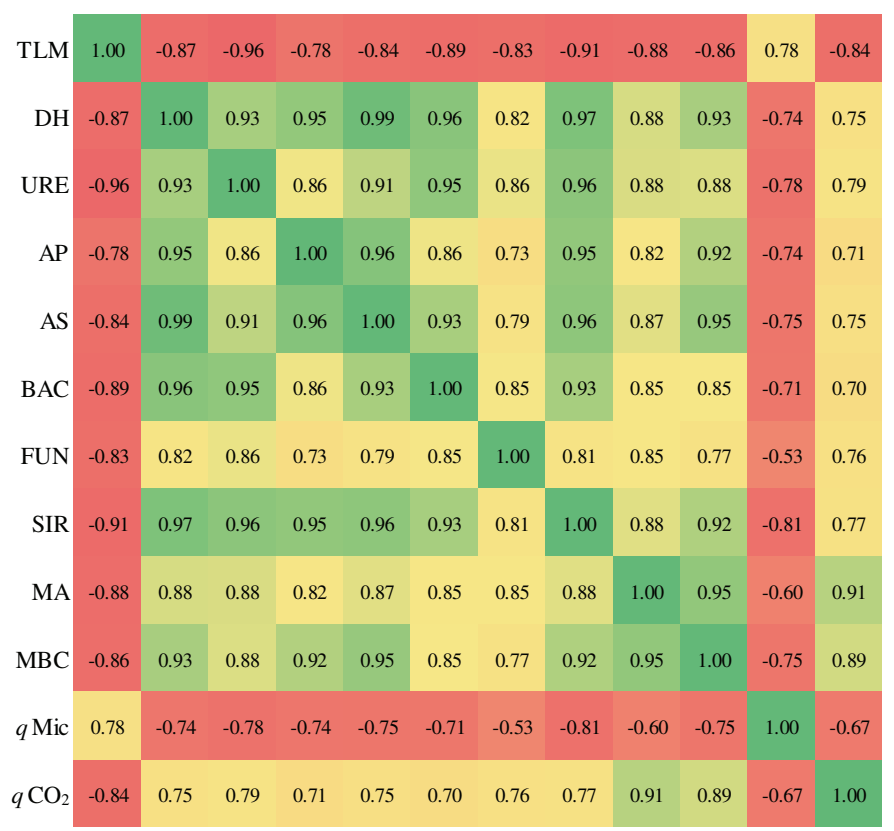

Fig. 5. Pearson's correlation analysis correlating (a) soil physicochemical properties and heavy metals (b) TLM, soil microbiological properties and enzyme activities $(n=56)(p<0.05)$. Green boxes show positive correlations; red boxes show negative correlations. Explanations: $\mathrm{pH}=$ Soil reaction, $\mathrm{OM}=$ Soil organic matter, $\mathrm{TN}=$ Total nitrogen, $\mathrm{AvP}=$ Available phosphorus, Clay = Clay content, $\mathrm{Cd}=$ Cadmium, $\mathrm{Cr}=$ Chromium, $\mathrm{Cu}=$ Cupper, $\mathrm{Ni}=$ Nickel, $\mathrm{Pb}=$ Lead, $\mathrm{Zn}=$ Zinc, $\mathrm{TLM}=$ Total load of extractable metals, $\mathrm{DH}=$ Dehydrogenase, URE= Urease, $\mathrm{AP}=$ Acid phosphatase, AS $=$ Arylsulfatase, $\mathrm{BAC}=$ The number of cultivable bacteria, $\mathrm{FUN}=$ The number of cultivable fungi, SIR=Substrate induced respiration, MA $=\mathrm{Mi}-$ crobial activity, $\mathrm{MBC}=$ Microbial biomass carbon, $q$ Mic $=$ Microbial quotient, $q \mathrm{CO}_{2}=$ Metabolic quotient
Table 7

Correlation coefficients among heavy metals and soil microbial and enzymatic properties

\begin{tabular}{|c|c|c|c|c|}
\hline \multicolumn{2}{|l|}{ Variables } & \multirow{2}{*}{ Equations } & \multirow{2}{*}{$\mathrm{R}^{2}$} & \multirow{2}{*}{$r$} \\
\hline Dependent & Independent & & & \\
\hline \multirow[t]{9}{*}{ Cadmium } & Bacteria & $y=-55.98 x+441.68$ & 0.75 & -0.86 \\
\hline & Fungi & $y=-81.46 x+713.58$ & 0.66 & -0.81 \\
\hline & SIR & $y=-5.12 x+65.62$ & 0.83 & -0.91 \\
\hline & MA & $y=-3.55 x+34.90$ & 0.77 & -0.88 \\
\hline & $\mathrm{MBC}$ & $y=-83.54 x+687.82$ & 0.74 & -0.86 \\
\hline & Dehydrogenases & $y=-84.61 x+708.03$ & 0.74 & -0.86 \\
\hline & Urease & $y=-5.60 x+53.77$ & 0.90 & -0.95 \\
\hline & Acid phosphatase & $y=-13.45 x+166.35$ & 0.60 & -0.77 \\
\hline & Arylsulfatase & $y=-12.13 x+82.94$ & 0.68 & -0.82 \\
\hline \multirow[t]{9}{*}{ Chromium } & Bacteria & $y=-2.10 x+576.77$ & 0.84 & -0.92 \\
\hline & Fungi & $y=-2.94 x+891.72$ & 0.69 & -0.83 \\
\hline & SIR & $y=-0.19 x+77.88$ & 0.93 & -0.96 \\
\hline & MA & $y=-0.13 x+43.45$ & 0.87 & -0.93 \\
\hline & $\mathrm{MBC}$ & $y=-3.29 x+912.42$ & 0.91 & -0.95 \\
\hline & Dehydrogenases & $y=-3.31 x+933.50$ & 0.90 & -0.95 \\
\hline & Urease & $y=-0.20 x+65.74$ & 0.92 & -0.96 \\
\hline & Acid phosphatase & $y=-0.56 x+206.66$ & 0.81 & -0.90 \\
\hline & Arylsulfatase & $y=-0.49 x+117.54$ & 0.88 & -0.94 \\
\hline \multirow[t]{9}{*}{ Cupper } & Bacteria & $y=-0.64 x+397.65$ & 0.75 & -0.87 \\
\hline & Fungi & $y=-0.94 x+649.56$ & 0.66 & -0.81 \\
\hline & SIR & $y=-0.06 x+61.02$ & 0.77 & -0.88 \\
\hline & MA & $y=-0.04 x+31.76$ & 0.72 & -0.85 \\
\hline & $\mathrm{MBC}$ & $y=-0.90 x+608.49$ & 0.66 & -0.81 \\
\hline & Dehydrogenases & $y=-0.94 x+633.62$ & 0.69 & -0.83 \\
\hline & Urease & $y=-0.06 x+49.22$ & 0.89 & -0.94 \\
\hline & Acid phosphatase & $y=-0.14 x+152.93$ & 0.51 & -0.72 \\
\hline & Arylsulfatase & $y=-0.13 x+71.81$ & 0.62 & -0.79 \\
\hline \multirow[t]{9}{*}{ Nickle } & Bacteria & $y=-1.75 x+395.67$ & 0.77 & -0.88 \\
\hline & Fungi & $y=-2.51 x+644.06$ & 0.67 & -0.82 \\
\hline & SIR & $y=-0.15 x+60.32$ & 0.73 & -0.85 \\
\hline & MA & $y=-0.10 x+31.18$ & 0.67 & -0.82 \\
\hline & $\mathrm{MBC}$ & $y=-2.30 x+592.45$ & 0.59 & -0.77 \\
\hline & Dehydrogenases & $y=-2.49 x+625.61$ & 0.68 & -0.82 \\
\hline & Urease & $y=-0.17 x+48.68$ & 0.87 & -0.93 \\
\hline & Acid phosphatase & $y=-0.36 x+150.34$ & 0.46 & -0.68 \\
\hline & Arylsulfatase & $y=-0.35 x+70.31$ & 0.59 & -0.77 \\
\hline \multirow[t]{9}{*}{ Lead } & Bacteria & $y=-0.28 x+387.52$ & 0.74 & -0.86 \\
\hline & Fungi & $y=-0.42 x+641.19$ & 0.69 & -0.83 \\
\hline & SIR & $y=-0.03 x+60.31$ & 0.77 & -0.88 \\
\hline & MA & $y=-0.02 x+31.29$ & 0.73 & -0.86 \\
\hline & MBC & $y=-0.40 x+597.84$ & 0.67 & -0.82 \\
\hline & Dehydrogenases & $y=-0.41 x+619.57$ & 0.68 & -0.83 \\
\hline & Urease & $y=-0.03 x+48.47$ & 0.90 & -0.95 \\
\hline & Acid phosphatase & $y=-0.06 x+151.67$ & 0.53 & -0.73 \\
\hline & Arylsulfatase & $y=-0.06 x+70.04$ & 0.62 & -0.79 \\
\hline \multirow[t]{9}{*}{ Zinc } & Bacteria & $y=-0.37 x+467.14$ & 0.79 & -0.89 \\
\hline & Fungi & $y=-0.52 x+741.61$ & 0.65 & -0.81 \\
\hline & SIR & $y=-0.03 x+68.09$ & 0.88 & -0.94 \\
\hline & MA & $y=-0.02 x+36.37$ & 0.80 & -0.89 \\
\hline & MBC & $y=-0.56 x+730.91$ & 0.80 & -0.89 \\
\hline & Dehydrogenases & $y=-0.56 x+750.17$ & 0.79 & -0.89 \\
\hline & Urease & $y=-0.04 x+55.85$ & 0.91 & -0.95 \\
\hline & Acid phosphatase & $y=-0.09 x+175.35$ & 0.70 & -0.84 \\
\hline & Arylsulfatase & $y=-0.08 x+89.83$ & 0.75 & -0.87 \\
\hline
\end{tabular}

All data are significant at a confidence interval of 95\%. Legend description in Fig. 5. 


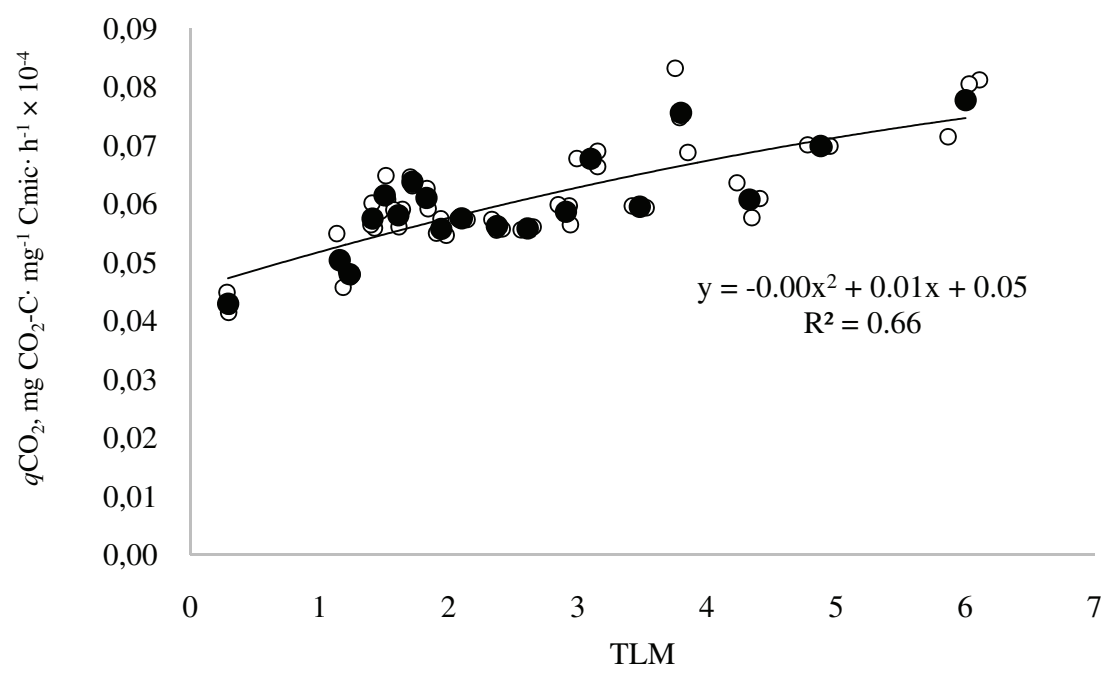

Fig. 6. Relationship of metabolic quotient $\left(q \mathrm{CO}_{2}\right)$ with total load of extractable metals (TLM) in different agricultural soils besides ship scrap processing sites, Sitakunda, Chattogram. Regression equation, line of the best fit and $\mathrm{R}^{2}$ is shown. Filled circles representing the average $q \mathrm{CO}_{2}$ values and open circles representing the replications inhibition of MBC in soils highly contaminated by heavy metals (Wyszkowska et al., 2013). The MA, apart from reflecting the rate of mineralization of soil $\mathrm{OM}$, reflects the respiratory activity of soil microorganisms, which is closely related to soil environmental quality (Schloter et al., 2018). Heavy metals may reduce soil MA by forming complexes with the substrates or by killing sensitive microorganisms (Landi et al., 2000). The synthesis of MBC in soils polluted by heavy metals can be less effective than in non-polluted soils due to the stress caused by heavy metals. Yang et al., (2006) stated that $\mathrm{Cd}, \mathrm{Pb}$ and $\mathrm{Zn}$ cause disorders in the soil MA and depress the MBC of microorganisms.

The $q$ Mic has been proposed as a useful measure of soil pollution of heavy metals (Wang et al., 2007). Our results confirm these findings, because the $q$ Mic values, expressing the maintenance energy, as the amount of heavy metal in soil increased (Table 6). Šmejkalová et al., (2003) was also found a significant decline of the $q \mathrm{Mic}$ with an increasing level of contamination. Soil microorganisms can be adapted to long-term heavy metal pollution by several mechanisms, such as precipitation of metals as phosphates, carbonates and sulfides, physical exclusion by exopolymers, and intracellular sequestration with low molecular weight compounds (Wang et al., 2007). This kind of cellular activity requires huge energy that increases the demand for maintenance energy. To survive in stress, soil microorganisms reduce the conversion of substrate into new $\mathrm{MBC}$ and other metabolic processes, therefore $q$ Mic decreased. A reduction of this ratio as a result of metal pollution has been reported from other studies (Valentim dos Santos et al., 2016). $q$ Mic also shows the survival capacity of soil microorganisms. Soil pollution due to heavy metal contamination is a serious problem because tolerant microorganisms can bioaccumulate heavy metals that directly affect the food chain to human health (Zhuang et al., 2009). On the other hand, soil microorganisms under environmental stress shift more energies from growth and reproduction to maintenance and survival, leading to an increase in $q \mathrm{CO}_{2}$ (Zhao et al., 2020). Our results show that the $q \mathrm{CO}_{2}$ increased markedly with increasing heavy metal concentration (Table 6). Zhang et al., (2008) also found the $q \mathrm{CO}_{2}$ as a good indicator of the negative impact of heavy metal pollution on soil microorganisms. A correlation study also demonstrated that $q \mathrm{CO}_{2}$ was negatively correlated with soil $\mathrm{MBC}$, microbial number and activity (Fig. 5) but $q \mathrm{CO}_{2}$ was significantly positively correlated with total heavy metals (TLM) (Fig. 6).

\subsection{Effect of heavy metals on soil enzyme activity}

The dehydrogenases, urease, acid phosphatase and arylsulfatase, enzymes involved in the C-N-P-S cycle in soil varied widely among the soils studied. The results demonstrated that the enzymatic activities of soil were lower than the reference site. The level of enzyme activity varied in a wide range and for dehydrogenases amounted 187.09 to $729.17 \mathrm{mg}$ formazan $\cdot \mathrm{kg}$ soil $^{-1} 24 \mathrm{~h}^{-1}$, for urease 13.48 to $50.22 \mathrm{mg} \mathrm{NH}-\mathrm{N} \cdot \mathrm{kg}$ soil $\cdot 2 \mathrm{~h}^{-1}$, for acid phosphatase 82.12 to $183.52 \mathrm{mg}$ p-nitrophenol.kg soil ${ }^{-1} \mathrm{~h}^{-1}$, and arylsulfatase 10.60 to $80.65 \mathrm{mg}$ p-nitrophenol $\mathrm{kg} \mathrm{soil}^{-1} \mathrm{~h}^{-1}$. The average enzyme activity is presented in Table 8 . On the reference site mean concentration of dehydrogenases, urease, acid phosphatase and arylsulfatase were $878.09 \mathrm{mg}$ formazan $\cdot \mathrm{kg}$ soil ${ }^{-}$ ${ }^{1} 24 \mathrm{~h}^{-1}, 53.06 \mathrm{mg} \mathrm{NH}_{4}-\mathrm{N} \cdot \mathrm{kg}$ soil $\cdot 2 \mathrm{~h}^{-1}, 217.46 \mathrm{mg}$ p-nitrophenol $\cdot \mathrm{kg}$ soil ${ }^{-1} \mathrm{~h}^{-1}$, and $119.11 \mathrm{mg}$ p-nitrophenol $\cdot \mathrm{kg}$ soil ${ }^{-1} \mathrm{~h}^{-1}$ respectively. Enzymatic activities were significantly $(p<0.05)$ low in the vegetable garden, vegetable field, paddy fields soils than in the reference site. A significant decrease in all the four enzyme activities was observed in the samples of agricultural soils near acid - leaching, burning and dismantling sites compared with the reference site (C). A significant positive correlation $(p<0.05)$ between dehydrogenases, urease, acid phosphatase and arylsulfatase was found in this study (Fig. 5).

Soil enzymes are biologically active soil components that have an intimate association with physicochemical and biological soil characteristics (Shukla and Varma, 2011). Soil enzyme activity is widely used as a reliable biological indicator to assess soil contamination but no quantitative standard of soil enzyme activity has been set to assess the level of heavy metal soil pollution. Generally, high enzyme activity represents good soil quality, while low activity may be related to the toxicity of heavy met- 
Table 8

Soil enzymes involved in soil C (dehydrogenases), N (urease), P (acid phosphatase) and S (arylsulfatase) (mean \pm SD) turnover in soils in different agricultural soils besides ship scrap processing sites, Sitakunda, Chattogram.

\begin{tabular}{|c|c|c|c|c|}
\hline \multirow[t]{2}{*}{ Legend } & Dehydrogenases & Urease & Acid phosphatase & Arylsulfatase \\
\hline & $\mathrm{mg}$ formazan $\cdot \mathrm{kg}$ soil $^{-1} 24 \mathrm{~h}^{-1}$ & $\mathrm{mg} \mathrm{NH}_{4}-\mathrm{N} \cdot \mathrm{kg}$ soil $\cdot 2 \mathrm{~h}^{-1}$ & mg p-nitrophenol $\cdot k g$ soil ${ }^{-1} \mathrm{~h}^{-1}$ & mg p-nitrophenol $\cdot \mathrm{kg}$ soil $^{-1} \mathrm{~h}^{-1}$ \\
\hline \multicolumn{5}{|l|}{ Vegetable garden } \\
\hline VG1 & $187.09 \pm 7.98^{\mathrm{a}}$ & $13.48 \pm 1.27^{\mathrm{a}}$ & $82.12 \pm 2.06^{\mathrm{a}}$ & $10.60 \pm 0.06^{\mathrm{a}}$ \\
\hline VG2 & $197.82 \pm 3.33^{\mathrm{ab}}$ & $14.94 \pm 0.15^{\mathrm{b}}$ & $85.84 \pm 2.82^{\mathrm{ab}}$ & $11.57 \pm 0.17^{\mathrm{ab}}$ \\
\hline VG3 & $217.59 \pm 1.71^{\mathrm{bc}}$ & $18.83 \pm 0.35^{c}$ & $89.63 \pm 2.95^{b}$ & $12.48 \pm 0.14^{\mathrm{bc}}$ \\
\hline VG4 & $612.61 \pm 37.03^{\mathrm{k}}$ & $48.18 \pm 0.68^{p}$ & $157.27 \pm 7.26^{\mathrm{i}}$ & $74.83 \pm 0.70^{\mathrm{m}}$ \\
\hline VG5 & $237.87 \pm 2.68^{\mathrm{cd}}$ & $29.29 \pm 0.17 \mathrm{e}$ & $101.80 \pm 1.66^{\text {cd }}$ & $17.13 \pm 0.34^{\mathrm{d}}$ \\
\hline VG6 & $408.81 \pm 6.47^{g}$ & $35.80 \pm 1.00^{j}$ & $108.26 \pm 3.28^{\mathrm{de}}$ & $34.49 \pm 0.61^{\mathrm{g}}$ \\
\hline VG7 & $280.44 \pm 24.79^{\mathrm{e}}$ & $30.94 \pm 0.12^{\mathrm{fg}}$ & $105.55 \pm 1.21^{\mathrm{d}}$ & $27.48 \pm 0.30^{\mathrm{e}}$ \\
\hline VG8 & $350.13 \pm 1.83^{\mathrm{f}}$ & $32.19 \pm 0.20^{\mathrm{h}}$ & $106.54 \pm 1.47^{d}$ & $30.22 \pm 0.24^{\mathrm{f}}$ \\
\hline \multicolumn{5}{|l|}{ Vegetable field } \\
\hline VF1 & $340.18 \pm 4.12^{\mathrm{f}}$ & $31.36 \pm 0.17^{\mathrm{gh}}$ & $106.24 \pm 0.64^{\mathrm{d}}$ & $28.12 \pm 0.46^{\mathrm{e}}$ \\
\hline VF2 & $363.36 \pm 2.00^{\mathrm{f}}$ & $33.51 \pm 0.53^{\mathrm{i}}$ & $108.26 \pm 0.33^{\mathrm{de}}$ & $33.06 \pm 0.10^{\mathrm{g}}$ \\
\hline VF3 & $256.34 \pm 2.19^{\text {de }}$ & $30.27 \pm 0.17^{f}$ & $104.26 \pm 0.23^{\mathrm{d}}$ & $17.90 \pm 0.35^{\mathrm{d}}$ \\
\hline VF4 & $440.30 \pm 6.03^{h}$ & $36.91 \pm 0.23^{k}$ & $114.78 \pm 2.13^{\text {ef }}$ & $37.74 \pm 0.85^{\mathrm{h}}$ \\
\hline VF5 & $457.71 \pm 6.46^{\mathrm{h}}$ & $39.26 \pm 1.13^{1}$ & $117.86 \pm 0.39^{f}$ & $47.47 \pm 0.47^{\mathrm{i}}$ \\
\hline VF6 & $529.32 \pm 3.38^{\mathrm{i}}$ & $40.89 \pm 0.15^{\mathrm{m}}$ & $121.41 \pm 0.49^{\mathrm{fg}}$ & $52.00 \pm 0.80^{j}$ \\
\hline \multicolumn{5}{|l|}{ Paddy field sites } \\
\hline $\mathrm{P} 1$ & $543.66 \pm 5.09^{j i}$ & $42.86 \pm 0.37^{n}$ & $127.30 \pm 2.53^{\text {gh }}$ & $55.46 \pm 0.66^{\mathrm{k}}$ \\
\hline $\mathrm{P} 2$ & $558.95 \pm 8.17^{j}$ & $45.99 \pm 0.25^{\circ}$ & $130.41 \pm 1.13^{\mathrm{h}}$ & $65.04 \pm 0.03^{1}$ \\
\hline P3 & $231.74 \pm 2.49^{c d}$ & $21.07 \pm 0.26^{\mathrm{d}}$ & $97.01 \pm 2.40^{c}$ & $13.30 \pm 0.17^{c}$ \\
\hline $\mathrm{P} 4$ & $729.17 \pm 37.08^{1}$ & $50.22 \pm 0.30^{q}$ & $183.52 \pm 12.23^{j}$ & $80.65 \pm 0.43^{n}$ \\
\hline \multicolumn{5}{|l|}{ Reference site } \\
\hline C & $878.29 \pm 20.72^{\mathrm{m}}$ & $53.06 \pm 0.59^{r}$ & $217.46 \pm 4.42^{\mathrm{k}}$ & $119.11 \pm 3.32^{\circ}$ \\
\hline \multicolumn{5}{|l|}{ Land use types } \\
\hline Vegetable garden & $311.54 \pm 138.30^{x}$ & $27.96 \pm 11.21^{x}$ & $104.63 \pm 22.67^{x}$ & $27.35 \pm 20.33^{x}$ \\
\hline Vegetable field & $397.87 \pm 91.35^{x y}$ & $35.37 \pm 4.09^{x y}$ & $112.14 \pm 6.52^{x}$ & $36.05 \pm 11.81^{x y}$ \\
\hline Paddy field & $515.88 \pm 188.17^{y}$ & $40.04 \pm 11.76^{y}$ & $134.56 \pm 32.97^{y}$ & $53.61 \pm 26.06^{y}$ \\
\hline Reference & $878.29 \pm 20.72^{z}$ & $53.06 \pm 0.59^{z}$ & $217.46 \pm 4.42^{z}$ & $119.11 \pm 3.32^{z}$ \\
\hline
\end{tabular}

Each mean is the average of the values obtained for three samples of each soil. Values in the same column followed by the same letter(s) are not significantly different at $p<0.05$ according to ANOVA. Sampling sites legend description in Table 2.

als pollutants to biological processes (Fazekašová and Fazekaš, 2020). Agricultural soils with high heavy metal concentrations showed reduced soil enzyme activities. The highest inhibitory effect on soil enzymes was observed in the most polluted soils. Soil enzymatic activity values were also correlated strongly and negatively with heavy metal concentrations. These findings express that if present at toxic concentration, heavy metals have a negative impact on soil enzyme activities. $\mathrm{Cr}$ and $\mathrm{Zn}$ had shown a very high significant negative correlation with the enzymesdehydrogenases, urease, acid phosphatase and arylsulfatase (Table 7). It was also observed that urease activity was the most affected by $\mathrm{Cr}$ while the least by $\mathrm{Ni}$. The heavy metal toxicity trend for toxicity impact for the enzyme was as follows: $\mathrm{Cr}>\mathrm{Cd}$ $=\mathrm{Zn}=\mathrm{Pb}>\mathrm{Cu}>\mathrm{Ni}$. $\mathrm{Cd}$ and $\mathrm{Cu}$, depress the activity of soil metals if present in excessive amounts (Kucharski et al., 2011). In turn, Speir et al., (1999) proved that $\mathrm{Cd}$ and $\mathrm{Ni}$ are stronger inhibitors than $\mathrm{Cu}$ and $\mathrm{Cr}$. For the heavy metals (Table 7) the decreasing trend of soil enzyme activities was as urease $>$ dehydrogenases $>$ arylsulfatase $>$ acid phosphatase. Results in our study showed that the urease and dehydrogenases activity were more sensitive to the heavy metal stress than the acid phosphatase activity. Zhang et al., (2013) showed dehydrogenases activity reduced in metal-contaminated soil compared to uncontaminated soil but soil phosphatase showed no response. Phosphatase activity can occur extracellularly along with within a living cell whereas dehydrogenases activity only acts inside a living cell (Wang et al., 2007). Therefore, microbial activity inhibited by heavy metal stresses directly expresses less dehydrogenases activity. 
$\mathrm{ED}_{50}$ values can be a suitable indicator of the sensitivity of an ecosystem to stress, because a $50 \%$ reduction of a basic ecological process may be too extreme for its continued functioning. Table 9 shows the four enzyme activities measured for the heavy metal contaminated agricultural soils and $\mathrm{ED}_{50}$ values calculated from the best fit model and $\mathrm{R}^{2}$ values from the regression analysis. Studies on the impact of toxic metals on soil enzymes showed the inhibition of these enzyme activities was always less than $100 \%$ of the control value. Model 1 was a full inhibition model. Model 2 was a partial inhibition model, suggesting that a fraction of the enzymatic activities were not inhibited by heavy metal contamination to the soil. Model 3 indicates that the relationship between enzyme activity and the toxicity coefficient is sigmoidal dose. It is very hard to interpret the reason for the decrease in soil enzyme activities as it may be due to a direct metal inhibition to enzymes or a lower synthesis and release of enzymes, or a combination of both (Gao et al., 2010). Enzymes in soils can be physically and chemically protected by soil constituents (organic and inorganic ligands), which interacted with trace elements (Renella et al., 2003), whereas enzyme was influenced by many factors not only heavy metal. Therefore, among the three models, Model 2 was the best fit in most of the cases. The $\mathrm{ED}_{50}$ values for dehydrogenases, acid phosphatase and arylsulfatase activity were predicted with Model 2, whereas the $\mathrm{ED}_{50}$ values for urease activity the best fit was achieved by the sigmoidal dose-response Model 3. The arylsulfatase was sensitive to the combined heavy metal effect and easily lost activity even at low heavy metal concentration. Dehydrogenases and urease activity were also sensitive to the combined heavy metal effect. The effect of heavy metal on acid phosphatase was found to be lower than the other enzymes as phosphatase activity was high heavy metal rate responsive to inhibit it.

A significant relationship between soil enzymes and PER as fitted by Model 2 and Model 3, also indicates an adaptation of soil microorganisms in our study area. Microorganisms differ in their sensitivity to metal toxicity and the development of metaltolerant strains could compensate for the loss of more sensitive populations (El Baz et al., 2015). The results of many experimental studies suggest that inhibition of soil enzymes due to heavy metal contamination can be reduced over time and some microorganisms could be adapted to long-term polluted environments and thereby help enzymatic activity to recover (Fazekašová and Fazekaš, 2020). Ship scraps dismantling activities are a long-time regular practice in this zone, therefore, the microorganism in our study site might be adapted to the high heavy metal concentration. Some of the heavy metal concentration was found to be at a very high toxic level in highly contaminated soils enough to suppress complete microbial activity, but due to their adaption capacity, they survived with limited enzyme activity.

\subsection{Effect of soil physicochemical properties and heavy metal interactions on soil microbial and enzyme activity}

The microbial population can be reduced by heavy metals which in turn can decrease the activities of soil enzymes. Consequently, the decomposition rate of carbon, nitrogen, phosphorus and sulfur in soils would be blocked. All the four enzymes were positively correlated $(p<0.05)$ with the number of cultivable bacterial and fungal populations, SIR, MA and MBC (Fig. 5). Dehydrogenases activity was significantly high in reference soil, where the soil microbiota was also metabolically more active than in contaminated agricultural soils (Table 6 and 8). Since dehydrogenases is an intracellular enzyme involved in microbial metabolism, their lower activity in agricultural soil may be related to the smaller MBC content, but also a higher heavy metal concentration in agricultural than in reference soils. Furthermore, the dehydrogenases activity was significantly correlated with MBC ( $r=0.93, p<0.05)$. The decrease of soil MBC and inhibition of dehydrogenases activity have been reported in polluted areas near an aluminium smelter with water-extractable fluoride concentration over $100 \mathrm{mg} \cdot \mathrm{kg}^{-1}$ in soil (Tscherko and Kandeler, 1997) These results suggest that MBC and dehydrogenases can be useful measures of the level of heavy metal contamination in a soil sample. Arylsulfatase, urease and acid phosphatase activity also showed a positive correlation with $\mathrm{MBC}(p<0.05)$, MA and $q \mathrm{CO}_{2}(p<0.05)$.

The effects of heavy metal contamination on enzyme activities can be mediated by soil pH (Dick, 2011), OM content (Tang et al., 2020) and clay content (Tietjen and Wetzel, 2003). Soil pH is one of the very important factors that are considered to evaluate the effect of pollutants on the activity of soil microorganisms, however, it is very difficult to separate the effect of heavy metal stress on soil microbial populations from that due to $\mathrm{pH}$ changes (García-Gil et al., 2013). Changing soil pH to an acidic level due to the soil management effect may intensify the heavy metal effect further (Wyszkowska et al., 2016). The decreasing pH leads to the increased bioavailability of $\mathrm{Cu}, \mathrm{Cd}, \mathrm{Zn}$ and $\mathrm{Pb}$ in soil (Aponte et al., 2020), which results in higher heavy metal toxicity for microorganisms and inhibition of enzyme activities. The nutrient content of the soil has a regulatory effect on the toxicity of heavy metals in soil (Chodak et al., 2013). But in our findings (Table 7 and 10), the effect of OM, TN, AvP on microorganisms was not as strong as that of heavy metal content. The changing

\section{Table 9}

Values of $\mathrm{R}^{2}(p<0.05)$ obtained for Gauss-Newton analysis, which best describe the inhibition of dehydrogenases, urease, acid phosphatase and arylsulfatase of different land-use type and $50 \%$ ecological dose $\left(E_{50}\right)$ expressed by total ecological toxicity coefficient (PER)

\begin{tabular}{lcrc}
\hline Enzyme & Model & $\mathrm{ED}_{50}$ & $\mathrm{R}^{2}$ \\
\hline Dehydrogenases & 2 & 3034.26 & 0.89 \\
Urease & 3 & 204.58 & 0.97 \\
Acid Phosphatase & 2 & 3564.02 & 0.86 \\
Arylsulfatase & 2 & 461.62 & 0.91 \\
\hline
\end{tabular}


Table 10

Correlation coefficients among physicochemical properties and soil microbial and enzymatic properties

\begin{tabular}{|c|c|c|c|c|}
\hline \multicolumn{2}{|l|}{ Variables } & \multirow{2}{*}{ Equation } & \multirow{2}{*}{$\mathrm{R}^{2}$} & \multirow{2}{*}{$r$} \\
\hline Dependent & Independent & & & \\
\hline \multirow[t]{9}{*}{$\mathrm{pH}$} & Bacteria & $\mathrm{y}=221.31 \mathrm{x}-867.23$ & 0.90 & 0.95 \\
\hline & Fungi & $y=295.12 x-1055.70$ & 0.67 & 0.82 \\
\hline & SIR & $y=19.15 x-48.62$ & 0.90 & 0.95 \\
\hline & MA & $y=11.84 x-37.06$ & 0.66 & 0.81 \\
\hline & $\mathrm{MBC}$ & $y=296.80 x-1097.20$ & 0.72 & 0.85 \\
\hline & Dehydrogenases & $y=335.65 x-1276.00$ & 0.89 & 0.94 \\
\hline & Urease & $y=20.04 x-66.61$ & 0.89 & 0.94 \\
\hline & Acid phosphatase & $y=55.24 x-158.50$ & 0.78 & 0.88 \\
\hline & Arylsulfatase & $y=49.45 x-208.18$ & 0.87 & 0.93 \\
\hline \multirow[t]{9}{*}{$\mathrm{OM}$} & Bacteria & $y=487.76 x-282.05$ & 0.66 & 0.81 \\
\hline & Fungi & $y=538.04 x-153.77$ & 0.33 & 0.58 \\
\hline & SIR & $y=42.71 x+1.49$ & 0.67 & 0.82 \\
\hline & MA & $y=23.776 x-3.26$ & 0.40 & 0.64 \\
\hline & $\mathrm{MBC}$ & $y=651.93 x-310.02$ & 0.52 & 0.72 \\
\hline & Dehydrogenases & $y=766.50 x-417.48$ & 0.70 & 0.84 \\
\hline & Urease & $y=40.63 x-9.79$ & 0.55 & 0.74 \\
\hline & Acid phosphatase & $y=134.65 x-26.42$ & 0.70 & 0.84 \\
\hline & Arylsulfatase & $y=114.86 x-83.79$ & 0.71 & 0.84 \\
\hline \multirow[t]{9}{*}{$\mathrm{TN}$} & Bacteria & $y=3175.90 x-248.03$ & 0.57 & 0.75 \\
\hline & Fungi & $y=4349.90 x-247.83$ & 0.45 & 0.67 \\
\hline & SIR & $y=325.96 x-2.97$ & 0.80 & 0.89 \\
\hline & MA & $y=194.06 x-7.70$ & 0.55 & 0.74 \\
\hline & $\mathrm{MBC}$ & $y=4971.50 x-377.48$ & 0.62 & 0.79 \\
\hline & Dehydrogenases & $y=5289.40 x-410.42$ & 0.68 & 0.83 \\
\hline & Urease & $y=303.82 x-13.058$ & 0.63 & 0.79 \\
\hline & Acid phosphatase & $y=972.69 x-31.94$ & 0.74 & 0.86 \\
\hline & Arylsulfatase & $y=765.50 x-78.52$ & 0.64 & 0.80 \\
\hline \multirow[t]{9}{*}{ AvP } & Bacteria & $y=43.72 x-208.56$ & 0.63 & 0.79 \\
\hline & Fungi & $y=72.12 x-320.81$ & 0.72 & 0.85 \\
\hline & SIR & $y=3.87 x+7.47$ & 0.66 & 0.81 \\
\hline & MA & $\mathrm{y}=2.87 \mathrm{x}-7.34$ & 0.70 & 0.84 \\
\hline & $\mathrm{MBC}$ & $y=61.29 x-241.43$ & 0.55 & 0.74 \\
\hline & Dehydrogenases & $y=63.98 x-252.81$ & 0.58 & 0.76 \\
\hline & Urease & $y=4.27 x-10.19$ & 0.73 & 0.85 \\
\hline & Acid phosphatase & $y=10.12 x+14.18$ & 0.47 & 0.69 \\
\hline & Arylsulfatase & $y=8.91 x-52.13$ & 0.51 & 0.71 \\
\hline \multirow[t]{9}{*}{ Clay } & Bacteria & $y=92.53 x-2460.10$ & 0.67 & 0.82 \\
\hline & Fungi & $y=130.44 x-3386.00$ & 0.55 & 0.74 \\
\hline & SIR & $y=7.33 x-166.60$ & 0.56 & 0.75 \\
\hline & MA & $y=4.65 x-113.61$ & 0.44 & 0.66 \\
\hline & $\mathrm{MBC}$ & $y=106.89 x-2730.60$ & 0.40 & 0.63 \\
\hline & Dehydrogenases & $y=127.30 x-3310.90$ & 0.55 & 0.74 \\
\hline & Urease & $y=8.64 x-218.37$ & 0.70 & 0.84 \\
\hline & Acid phosphatase & $y=18.61 x-424.89$ & 0.38 & 0.61 \\
\hline & Arylsulfatase & $y=18.54 x-501.80$ & 0.52 & 0.72 \\
\hline
\end{tabular}

All data are significant at a confidence interval of 95\%. Legend description in Fig. 5. redox potential in paddy soils can control the mobility, potential toxicity and ultimate fate of heavy metals in these soils. Consequently, the concentrations of soluble $\mathrm{Pb}, \mathrm{Cd}, \mathrm{Zn}$ and $\mathrm{Cu}$ from paddy fields with aerobic-anaerobic cycles can be slightly lower than those aerated with oxygen (Li et al., 2018). Besides, the nonuniform distribution of scrap processing activities related to land-use practices causes some anomalous soil properties. Paddy soil exhibited high large arylsulfatase and acid phosphatase activities, which may indicate less stress compared to vegetable garden soil due to the changing redox conditions. Moreover, at improved $\mathrm{pH}$ conditions from very acid to the moderately acidic situation (paddy soil), the bioavailability of heavy metals may be reduced, but the improved $\mathrm{pH}$ conditions may affect not only microbial numbers and activities but also soil enzyme activity (García-Gil et al., 2013).

\subsection{Effect of total load of extractable heavy metals (TLM) on soil microbial and enzyme activity}

All the heavy metals measured from a certain site together can be used as TLM to predict the toxicity of heavy metals of that site to the soil microorganisms, which would explain the influence of combined pollution on soil microbial activity. Furthermore, compared with one single metal, multiple heavy metals in soil behave interactively and show combined ecological influence in nature. Heavy metals in combined impact can have synergistic or antagonistic effects on soil enzymes as they influence the absorption, distribution and usage of each other. Heavy metals can have different inhibiting orders on enzyme activities (Gülser and Erdođan, 2008). The results of this study found suppression of all the soil microbial properties and enzyme activities, which indicated the disruption of soil function by the heavy metal contamination in the vicinity of ship scrap processing sites. The $q \mathrm{CO}_{2}$, which expresses the stress situation on soil microorganisms, with increasing TLM was fitted by the exponential curve (Fig. 6). Correlation analysis produced significant relationships between TLM versus all the microbial properties and enzyme activities (Fig. 5). All of the measured parameters showed a significant decline with increasing TLM and the reduction was particularly evident at the highest TLM values (sites VG1, VG2, VG3, P3, VG5 and VF3). The inhibitory effect of $\mathrm{Cd}$ and Pb on the urease, acid phosphatase and dehydrogenases enzyme activity was greater when combined than single heavy metal (Pan and $\mathrm{Yu}, 2011$ ), this was also supported by $\mathrm{Cd}, \mathrm{Pb}$ and $\mathrm{Zn}$ combination (Yang et al., 2006). Whereas $\mathrm{Cu}$ toxicity was greater as single metal than in combination with $\mathrm{Cd}, \mathrm{Cr}, \mathrm{Ni}, \mathrm{Pb}$ and $\mathrm{Zn}$ (Wyszkowska et al., 2006). Therefore, heavy metal type and concentration in their combined action influence the synergistic or antagonistic effect of heavy metals on soil microbial and enzyme activity.

\subsection{Characterization of agricultural soils around ship scrap processing sites}

A PCA was performed on a correlation matrix of the data obtained on soil microbial and enzymatic activities affected by soil physicochemical properties and heavy metal content (Fig. 7). The correlation circle revealed a strong relationship 
Variables (axes F1 and F2: $45.36 \%$ )

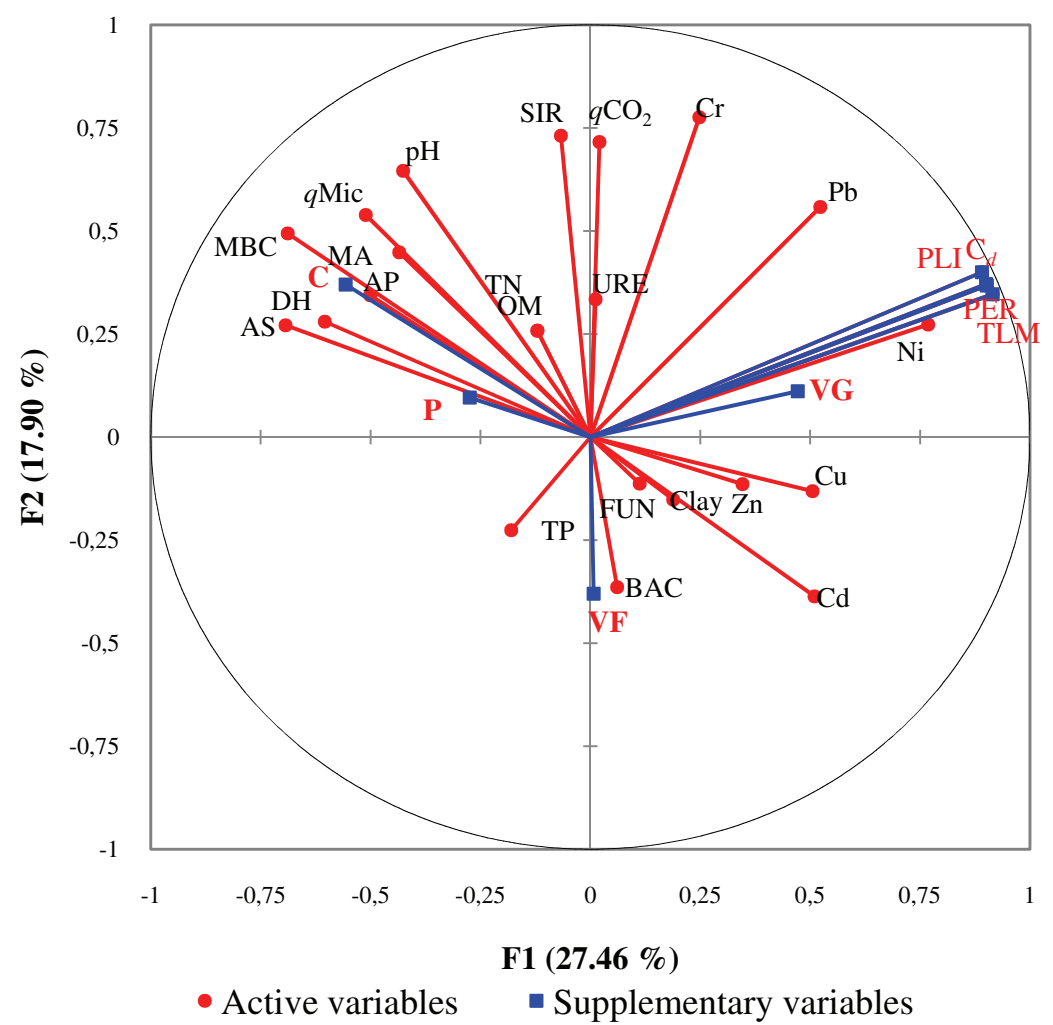

Fig. 7. Results of principal component analysis (PCA) of soil microbial activity and enzyme activity in soil contaminated with heavy metals in different agricultural soils besides ship scrap processing sites, Sitakunda, Chattogram. Explanations: $\mathrm{pH}=$ Soil reaction, $\mathrm{OM}=$ Soil organic matter, $\mathrm{TN}=$ Total nitrogen, AvP = Available phosphorus, Clay = = Clay content, $\mathrm{Cd}=$ Cadmium, $\mathrm{Cr}=$ Chromium, $\mathrm{Cu}=$ Cupper, $\mathrm{Ni}=$ Nickel, $\mathrm{Pb}=$ Lead, $\mathrm{Zn}=$ Zinc, $\mathrm{TLM}=$ Total load of extractable metals, $\mathrm{DH}=$ Dehydrogenase, URE = Urease, $\mathrm{AP}=$ Acid Phosphatase, $\mathrm{AS}=$ Arylphophatase, $\mathrm{BAC}=$ The number of cultivable bacteria, $\mathrm{FUN}=$ The number of cultivable fungi, SIR = Substrate induced respiration, $\mathrm{MA}=$ Microbial activity, $\mathrm{MBC}=$ Microbial biomass carbon, $q \mathrm{Mic}=$ Microbial quotient, $q \mathrm{CO}_{2}=$ Metabolic quotient, $P L I=$ Pollution load index, $\mathrm{C}_{d}=$ Integrated pollution degree, $P E R=$ Potential ecological risk, TLM $=$ Total load of extractable metals, VG = Vegetable garden site, $\mathrm{VF}=$ Vegetable field site, $\mathrm{P}=$ Paddy field site, $\mathrm{C}=$ Reference site between enzymatic activities and soil microbial properties, and they varied together in the same trend upon toxic impact from heavy metals. The PCA analysis showed that microbial biomass and activities (MA and SIR) and all the enzyme activities were highly associated with soil $\mathrm{pH}, \mathrm{OM}$ and TN. There was a very close association between all the heavy metal indices. $\mathrm{Cr}, \mathrm{Pb}, \mathrm{Ni}$ and $\mathrm{Cu}, \mathrm{Cd}$ and $\mathrm{Zn}$ were significantly and positively associated with all the indices of heavy metal and $q \mathrm{CO}_{2}$. Dehydrogenases, acid phosphatase and arylsulfatase responded similarly to soil contamination with heavy metals, which is demonstrated by the proximity of vectors representing the analyzed enzymes. Urease was also sensitive to heavy metals, but its response to heavy metals was somewhat different. This is illustrated by the position of the urease vector relative to cases representing the soil heavy metal indices (TLM, $P E R, C_{d}$ and $P L I$ ). The distribution of sampling area (VG, VF, P and C) in the PCA plot also manifests the difference between them. Gao et al., (2010) showed that absolute enzymatic activities varied under different land uses depending on the types of land use or management and the type of enzyme.

Dendrogram grouping of heavy metal contaminated soils characterized by similar responses of soil microorganisms and their enzyme activity to heavy metal concentration and respective heavy metal indices along with soil physicochemical properties were performed (Fig. 8). The dendrogram revealed two main clusters of similarities with heavy metal contaminated soils. A cluster that contained P4, VG4 and C was significantly different from the other agricultural soils. As P4 and VG4 are clustered together with reference site, we can tell that the environmental situation in these soils with a combination of mul- tiple heavy metals with physicochemical characteristics of the soils, were not under any stressed condition. Among the contaminated sites, there were two clusters and a cluster that contained only one element VG1 was significantly different from the other contaminated sites. The soil of this site is at the highest pollution level as supported by heavy metal indices and the related responses of microbial and enzyme activities.

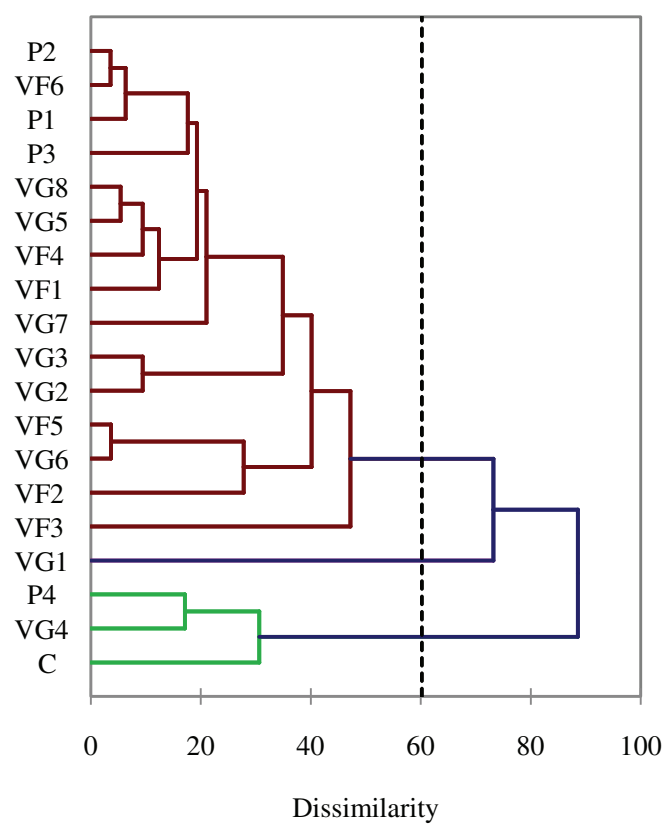

Fig. 8. Similarity dendrogram for sampling sites. Sampling sites legend description in Table 2 


\section{Conclusions}

Investigation on the heavy metal concentration and heavy metal indices from the agricultural soils in the vicinity of ship scrap processing activities showed that:

- the heavy metal contents of the soil were at a high pollution level,

- the physicochemical properties especially the $\mathrm{pH}$ of these soils played an important role in enhancing the bioavailability of heavy metals,

- at the current pollution level, the heavy metals in the soil of the shipbreaking area affect the soil quality as they exhibit a significant inhibitory effect on the soil microbial and enzyme activity,

- due to the emerging environmental issues of heavy metal contamination in agricultural soils, high amounts of multiple heavy metal pollutants in contaminated soil need further study to confirm the enzyme kinetics and mechanisms for the effects of heavy metal interaction,

- the area under the impact of shipbreaking is becoming wide-spread in Chattogram and includes major cropping and forested zones in coastal areas. Further studies on the possibility of toxic effect mechanism for heavy metal in soil enzyme and microbiological activities and translocation to vegetable plants growing in the area are necessary,

- the results obtained in this study are alarming and the Government authorities of Chattogram in Bangladesh should undertake appropriate strategies to establish rules of safe working near shipyards for people and protecting the environment from heavy metal contaminations.

\section{Acknowledgments}

The authors thank Mr. Tazul Islam for technical assistance in soil processing.

\section{References}

Abdu, N., Abdullahi, A.A., Abdulkadir, A., 2017. Heavy metals and soil microbes. Environmental Chemistry Letters 15(1), 65-84. https://doi. org/10.1007/s10311-016-0587-x

Adesokan, M.D., Adie, G.U., Osibanjo, O., 2016. Soil pollution by toxic metals near e-waste recycling operations in Ibadan, Nigeria. Journal of Health and Pollution 6(11), 26-33. https://doi.org/10.5696/2156-96146-11.26

Adimalla, N., Li, P., 2019. Occurrence, health risks and geochemical mechanisms of fluoride and nitrate in groundwater of the rock-dominant semi-arid region, Telangana State, India. Human and Ecological Risk Assessment: An International Journal 25(1-2), 81-103. https://doi. org/10.1080/10807039.2018.1480353

Ahmed, M.J., Uddin, M.N., Islam, M.N., Islam, M.S., Abdullah, M., 2013. Physicochemical assessment of soil pollutants due to the ship breaking activities and its impact on the coastal zone of Chittagong, Bangladesh. European Chemical Bulletin 2(12), 975-980. http://dx.doi. org/10.17628/ecb.2013.2.975-980

Akmal, M., Jianming, X., 2009. Microbial biomass and bacterial community changes by $\mathrm{Pb}$ contamination in acidic soil. Journal of Agriculture and Biological Sciences 1(1), 30-37.

Aktaruzzaman, M., Chowdhury, M.A.Z., Fardous, Z., Alam, M.K., Hossain, M.S., Fakhruddin, A.N.M., 2014. Ecological risk posed by heavy met- als contamination of ship breaking yards in Bangladesh. International Journal of Environmental Research 8(2), 469-478. https://doi. org/10.22059/IJER.2014.739

Alam, I., Barua, S., Ishii, K., Mizutani, S., Hossain, M.M., Rahman, I.M., Hasegawa, H., 2019. Assessment of health risks associated with potentially toxic element contamination of soil by end-of-life ship dismantling in Bangladesh. Environmental Science and Pollution Research 26(23), 24162-24175. https://doi.org/10.1007/s11356-019-05608-x

Alam, S.S., Osman, K.T., Kibria, M.G., 2012. Heavy metal pollution of soil from industrial and municipal wastes in Chittagong, Bangladesh. Archives of Agronomy and Soil Science 58(12), 1427-1438. https://doi. org/10.1080/03650340.2011.596826

Alamgir, M., Islam, M., Hossain, N., Kibria, M.G., Rahman, M.M., 2015. Assessment of heavy metal contamination in urban soils of Chittagong City, Bangladesh. International Journal of Plant and Soil Science 7(6), 362-372. https://doi.org/10.9734/IJPSS/2015/18424

Alef, K., Nannipieri, P., 1995. Methods in applied soil microbiology and biochemistry (No. 631.46 M592ma). Academic Press.

Ali, M.M., Ali, M.L., Islam, M.S., Rahman, M.Z., 2016. Preliminary assessment of heavy metals in water and sediment of Karnaphuli River, Bangladesh. Environmental Nanotechnology, Monitoring and Management 5, 27-35. https://doi.org/10.1016/j.enmm.2016.01.002

Anderson, J.M., Ingram, J.S.I., 1993. A handbook of methods. CAB International, Wallingford, Oxfordshire, 221.

Anderson, T.H., Domsch, K.H., 1989. Ratios of microbial biomass carbon to total organic carbon in arable soils. Soil Biology and Biochemistry 21(4), 471-479. https://doi.org/10.1016/0038-0717(89)90117-X

Anderson, T.H., Domsch, K.H., 1990. Application of eco-physiological quotients $\left(q \mathrm{CO}_{2}\right.$ and $\left.q \mathrm{D}\right)$ on microbial biomasses from soils of different cropping histories. Soil Biology and Biochemistry 22(2), 251-255. https://doi.org/10.1016/0038-0717(90)90094-g

Aponte, H., Meli, P., Butler, B., Paolini, J., Matus, F., Merino, C., Cornejo, P., Kuzyakov, Y., 2020. Meta-analysis of heavy metal effects on soil enzyme activities. Science of the Total Environment 737, 139744. https://doi.org/10.1016/j.scitotenv.2020.139744

Casida, L.E., 1977. Microbial metabolic activity in soil as measured by dehydrogenases determinations. Applied and Environmental Microbiology 34(6), 630-636.

CCME (Canadian Council of Ministers of the Environment), 2003. Canadian environmental quality guidelines. https://www.ccme.ca/en/resources/canadian_environmental_quality_guidelines/

Chen, S.B., Meng, W.A.N.G., Li, S.S., Zhao, Z.Q., Wen-di, E., 2018. Overview on current criteria for heavy metals and its hint for the revision of soil environmental quality standards in China. Journal of Integrative Agriculture 17(4), 765-774. https://doi.org/10.1016/S20953119(17)61892-6

Chodak, M., Gołębiewski, M., Morawska-Płoskonka, J., Kuduk, K., Niklińska, M., 2013. Diversity of microorganisms from forest soils differently polluted with heavy metals. Applied Soil Ecology 64, 7-14. https://doi.org/10.1016/j.apsoil.2012.11.004

Chowdhury, N., Rasid, M.M., 2016. Heavy metal contamination of soil and vegetation in ambient locality of ship breaking yards in Chittagong, Bangladesh. IOSR Journal of Environmental Science, Toxicology and Food Technology 10(10), 20-27. https://doi.org/10.9790/24021010022027

Day, P.R., 1965. Particle fractionation and particle size analysis. [In:] Black, C.A., (Ed.) Methods of soil analysis: Part 1 Physical and Mineralogical Properties, Including Statistics of Measurement and Sampling. Agronomy 9, American Society of Agronomy, Inc., Madison, Wisconsin, USA.

DEC (Department of Environment and Conservation)., 2010. Assessment levels for soil, sediment and water. Version 4, revision 1. Perth, Australia.

Dick, W.A., 2011. Development of a soil enzyme reaction assay. [In:] Dick R.P., (Ed.) Methods of Soil Enzymology. 9, Science Society of America, Inc. 71-84. https://doi.org/10.2136/sssabookser9.c4 
Eivazi, F., Tabatabai, M.A., 1977. Phosphatases in soils. Soil Biology and Biochemistry 9(3), 167-172.

El Baz, S., Baz, M., Barakate, M., Hassani, L., El Gharmali, A., Imziln, B., 2015. Resistance to and accumulation of heavy metals by actinobacteria isolated from abandoned mining areas. The Scientific World Journal 2015. https://doi.org/10.1155/2015/761834

Fazekašová, D., Fazekaš, J., 2020. Soil quality and heavy metal pollution assessment of iron ore mines in Nizna Slana (Slovakia). Sustainability 12(6), 2549. https://doi.org/10.3390/su12062549

Gao, Y., Zhou, P., Mao, L., Zhi, Y.E., Shi, W.J., 2010. Assessment of effects of heavy metals combined pollution on soil enzyme activities and microbial community structure: modified ecological dose-response model and PCR-RAPD. Environmental Earth Sciences 60(3), 603-612. https://doi.org/10.1007/s12665-009-0200-8

García-Gil, J.C., Kobza, J., Soler-Rovira, P., Javoreková, S., 2013. Soil microbial and enzyme activities response to pollution near an aluminium smelter. Clean-Soil, Air, Water 41(5), 485-492. https://doi.org/10.1002/ clen.201200099

Gülser, F., Erdođan, E., 2008. The effects of heavy metal pollution on enzyme activities and basal soil respiration of roadside soils. Environmental Monitoring and Assessment 145(1-3), 127-133. https://doi. org/10.1007/s10661-007-0022-7

Guo, W., Liu, X., Liu, Z., Li, G., 2010. Pollution and potential ecological risk evaluation of heavy metals in the sediments around Dongjiang Harbor, Tianjin. Procedia Environmental Sciences 2, 729-736. https://doi. org/10.1016/j.proenv.2010.10.084

Hasan, A.B., Kabir, S., Reza, A.S., Zaman, M.N., Ahsan, A., Rashid, M., 2013. Enrichment factor and geo-accumulation index of trace metals in sediments of the ship breaking area of Sitakund Upazilla (BhatiaryKumira), Chittagong, Bangladesh. Journal of Geochemical Exploration 125, 130-137. https://doi.org/10.1016/j.gexplo.2012.12.002

Hasan, A.B., Reza, A.S., Kabir, S., Siddique, M.A.B., Ahsan, M.A., Akbor, M.A., 2020. Accumulation and distribution of heavy metals in soil and food crops around the ship breaking area in southern Bangladesh and associated health risk assessment. SN Applied Sciences 2(2), 1-18. https://doi.org/10.1007/s42452-019-1933-y

Hossain, M.M.M., Islam, M.M., 2006. Ship breaking activities and its impact on the coastal zone of Chittagong, Bangladesh: Towards sustainable management. Young Power in Social Action (YPSA), Chittagong, Bangladesh.

Huq, S.I., Shoaib, J.M., 2013. The soils of Bangladesh. Springer, Dordrecht.

Islam, M.S., Ahmed, M.K., Habibullah-Al-Mamun, M., Hoque, M.F., 2015. Preliminary assessment of heavy metal contamination in surface sediments from a river in Bangladesh. Environmental Earth Sciences 73(4), 1837-1848. https://doi.org/10.1007/s12665-014-3538-5

Islam, M.S., Hoque, M.F., 2014. Concentrations of heavy metals in vegetables around the industrial area of Dhaka city, Bangladesh and health risk assessment. International Food Research Journal, 21(6), 2121-2126.

Jackson, M.L., 1973. Soil chemical analysis. Prentice Hall of India Ltd. New Delhi.

Jiang, J., Wu, L., Li, N., Luo, Y., Liu, L., Zhao, Q., Zhang, L., Christie, P., 2010. Effects of multiple heavy metal contamination and repeated phytoextraction by Sedum plumbizincicola on soil microbial properties. European Journal of Soil Biology 46(1), 18-26. https://doi.org/10.1016/ j.ejsobi.2009.10.001

Johnson, L.F., Curl, E.A., 1972. Methods for research on the ecology of soilborne plant pathogens (No. 04; QR111, J6.). Minneapolis: Burgess.

Khan, S., Cao, Q., Zheng, Y.M., Huang, Y.Z., Zhu, Y.G., 2008. Health risks of heavy metals in contaminated soils and food crops irrigated with wastewater in Beijing, China. Environmental Pollution 152(3), 686692. https://doi.org/10.1016/j.envpol.2007.06.056

Kucharski, J., Wieczorek, K., Wyszkowska, J., 2011. Changes in the enzymatic activity in sandy loam soil exposed to zinc pressure. Journal of Elementology 16(4), 577-589. https://doi.org/10.5601/jelem.2011.16.4.07
Kuźniar, A., Banach, A., Stępniewska, Z., Frąc, M., Oszust, K., Gryta, A., Kłos, M., Wolińska, A., 2018. Community-level physiological profiles of microorganisms inhabiting soil contaminated with heavy metals. International Agrophysics 32(1), 101-109. https://doi.org/10.1515/intag-2016-0096

Landi, L., Renella, G., Moreno, J.L., Falchini, L., Nannipieri, P., 2000. Influence of cadmium on the metabolic quotient, L-: D-glutamic acid respiration ratio and enzyme activity: microbial biomass ratio under laboratory conditions. Biology and Fertility of Soils 32(1), 8-16. https://doi.org/10.1007/s003740000205

Li, Q., Hu, Q., Zhang, C., Jin, Z., 2018. Effects of Pb, Cd, Zn, and Cu on soil enzyme activity and soil properties related to agricultural land-use practices in Karst area contaminated by $\mathrm{Pb}-\mathrm{Zn}$ tailings. Polish Journal of Environmental Studies 27(6), 2623-2632. https://doi.org/10.15244/ pjoes/81213

Liu, W.X., Shen, L.F., Liu, J.W., Wang, Y.W., Li, S.R., 2007. Uptake of toxic heavy metals by rice (Oryza sativa L.) cultivated in the agricultural soil near Zhengzhou City, People's Republic of China. Bulletin of Environmental Contamination and Toxicology 79(2), 209-213. https://doi. org/10.1007/s00128-007-9164-0

Misbahuzzaman, K., Alam, M.J., 2006. Ecological restoration of rainforest through aided natural regeneration in the denuded hills of Sitakunda, Chittagong, Bangladesh. International Journal of Agriculture and Biology 8(6), 778-782.

Muller, G., 1969. Index of geoaccumulation in sediments of the Rhine River. Geojournal 2, 108-118.

Nelson, D.W., Sommers, L.E., 1982. Total carbon, organic carbon, and organic matter. [In:] Page A.L., Miller. R.H., Keeney, D.R. (Eds.) Methods of soil analysis. Part 2. Chemical and Microbiological Properties. Agronomy Monograph 9, ASA and SSSA, Madison, WI.

Pan, J., Yu, L., 2011. Effects of Cd or/and Pb on soil enzyme activities and microbial community structure. Ecological Engineering 37(11),18891894. https://doi.org/10.1016/j.ecoleng.2011.07.002

Proshad, R., Islam, M.S., Kormoker, T., 2018. Assessment of heavy metals with ecological risk of soils in the industrial vicinity of Tangail district, Bangladesh. International Journal of Advanced Geosciences 6(1), 108-116. https://doi.org/10.14419/ijag.v6i1.9791

Proshad, R., Kormoker, T., Islam, S., 2019. Distribution, source identification, ecological and health risks of heavy metals in surface sediments of the Rupsa River, Bangladesh. Toxin Reviews 1-25. https://doi.org/1 0.1080/15569543.2018.1564143

Rahman, I.M., Mutsuddi, R., Jii, N., Barua, S., Ahmmad, B., Kibria, M.G., Hossain, M.M., Begum, Z.A., Dey, B.K., Hasegawa, H., 2019a. Does open-beach ship-breaking affect the mineralogical composition of soil more adversely than typical industrial activities? Journal of Environmental Management 240, 374-383. https://doi.org/10.1016/ j.jenvman.2019.03.107

Rahman, M.S., Hossain, M.B., Babu, S.O.F., Rahman, M., Ahmed, A.S., Jolly, Y.N., Choudhury, T.R., Begum, B.A., Kabir, J., Akter, S., 2019b. Source of metal contamination in sediment, their ecological risk, and phytoremediation ability of the studied mangrove plants in ship breaking area, Bangladesh. Marine Pollution Bulletin 141, 137-146. https://doi. org/10.1016/j.marpolbul.2019.02.032

Renella, G., Ortigoza, A.R., Landi, L., Nannipieri, P., 2003. Additive effects of copper and zinc on cadmium toxicity on phosphatase activities and ATP content of soil as estimated by the ecological dose $\left(\mathrm{ED}_{50}\right)$. Soil Biology and Biochemistry 35(9), 1203-1210. https://doi.org/10.1016/ S0038-0717(03)00181-0

Rieuwerts, J.S., Thornton, I., Farago, M.E., Ashmore, M.R., 1998. Factors influencing metal bioavailability in soils: preliminary investigations for the development of a critical loads approach for metals. Chemical Speciation and Bioavailability 10(2), 61-75. https://doi.org/10.3184/09 5422998782775835

Rodella, A.A., Saboya, L.V., 1999. Calibration for conductimetric determination of carbon dioxide. Soil Biology and Biochemistry 31(14), 
2059-2060. https://doi.org/10.1016/s0038-0717(99)00046-2

Schloter, M., Nannipieri, P., Srrrensen, S.J., van Elsas, J.D., 2018. Microbial indicators for soil quality. Biology and Fertility of Soils 54(1), 1-10. https://doi.org/10.1007/s00374-017-1248-3

Shukla, G., Varma, A., 2011. Soil enzymology. Springer-Verlag Berlin Heidelberg, Series Volume 22, XVI, 384. https://doi.org/10.1007/978-3-64214225-3

Simona, C., Angela, R.F., de Santo Amalia, V., 2004. Suitability of soil microbial parameters as indicators of heavy metal pollution. Water, Air, and Soil Pollution 158(1), 21-35. https://doi.org/10.1023/B: WATE.0000044824.88079.d9

Smejkalova, M., Mikanova, O., Boruvka, L., 2003. Effects of heavy metal concentrations on biological activity of soil micro-organisms. Plant Soil and Environment 49(7), 321-326.

Speir, T.W., Kettles, H.A., Percival, H.J., Parshotam, A., 1999. Is soil acidification the cause of biochemical responses when soils are amended with heavy metal salts? Soil Biology and Biochemistry 31(14), 19531961. https://doi.org/10.1016/S0038-0717(99)00115-7

Suresh, G., Ramasamy, V., Sundarrajan, M., Paramasivam, K., 2015. Spatial and vertical distributions of heavy metals and their potential toxicity levels in various beach sediments from high-background-radiation area, Kerala, India. Marine Pollution Bulletin 91(1), 389-400. https:// doi.org/10.1016/j.marpolbul.2014.11.007

Tabatabai, M.A., Bremner, J.M., 1970. Arylsulfatase activity of soils. Soil Science Society of America Journal 34(2), 225-229.

Tabatabai, M.A., Bremner, J.M., 1972. Assay of urease activity in soils. Soil Biology and Biochemistry 4(4), 479-487.

Tang, J., Zhang, L., Zhang, J., Ren, L., Zhou, Y., Zheng, Y., Luo, L., Yang, Y., Huang, H., Chen, A., 2020. Physicochemical features, metal availability and enzyme activity in heavy metal-polluted soil remediated by biochar and compost. Science of the Total Environment 701, 134751. https://doi.org/10.1016/j.scitotenv.2019.134751

Tietjen, T., Wetzel, R.G., 2003. Extracellular enzyme-clay mineral complexes: Enzyme adsorption, alteration of enzyme activity, and protection from photodegradation. Aquatic Ecology 37(4), 331-339. https://doi. org/10.1023/B:AECO.0000007044.52801.6b

Tscherko, D., Kandeler, E., 1997. Ecotoxicological effects of fluorine deposits on microbial biomass and enzyme activity in grassland. European Journal of Soil Science 48(2), 329-335. https://doi.org/10.1111/ j.1365-2389.1997.tb00553.x

Ure, A.M., 1990. Methods of Analysis for Heavy metals in soils. [In:] Alloway, B.J., (Ed.) Heavy Metals in soils. Blackie \& Son Ltd. Bishopbriggs, UK.

Valentim dos Santos, J., Varón-López, M., Fonsęca Sousa Soares, C., Lopes Leal, P., José Oswaldo Siqueira, P., Maria de Souza Moreira, F., 2016. Biological attributes of rehabilitated soils contaminated with heavy metals. Environmental Science and Pollution Research 23, 6735-6748. https://doi.org/10.1007/s11356-015-5904-6

VROM (Dutch Ministry of Housing, Spatial Planning and Environment)., 2000. The Circular on Target Values and Intervention Values for Soil Remediation. Ministry of Housing, Spatial Planning and the Environment, the Netherlands. https://www.esdat.net/environmental\%20sta ndards/dutch/annexs_i2000dutch\%20environmental\%20standards. pdf

Wang, A.J., Kawser, A., Xu, Y.H., Ye, X., Rani, S., Chen, K.L., 2016. Heavy metal accumulation during the last 30 years in the Karnaphuli River estuary, Chittagong, Bangladesh. SpringerPlus 5(2079). https://doi. org/10.1186/s40064-016-3749-1

Wang, Y., Shi, J., Wang, H., Lin, Q., Chen, X., Chen, Y., 2007. The influence of soil heavy metals pollution on soil microbial biomass, enzyme activity, and community composition near a copper smelter. Ecotoxicology and Environmental Safety 67(1), 75-81. https://doi.org/10.1016/ j.ecoenv.2006.03.007

Website 1. Map of Sitakunda Upazila, http://en.banglapedia.org/index. php?title=File:SitakunduUpazila.jpg
Website 2. Natural Resources Conservation Service Soils of the United States Department of Agriculture. https://www.nrcs.usda.gov/wps/ portal/nrcs/detail/soils/survey/?cid=nrcs142p2_054167

West, A.W., Sparling, G.P., 1986. Modifications to the substrate-induced respiration method to permit measurement of microbial biomass in soils of differing water contents. Journal of Microbiological Methods 5(3-4), 177-189.

Wolińska, A., Kuźniar, A., Zielenkiewicz, U., Banach, A. and Błaszczyk, M., 2018. Indicators of arable soils fatigue-Bacterial families and genera: A metagenomic approach. Ecological Indicators 93, 490-500. https:// doi.org/10.1016/j.ecolind.2018.05.033

Wolińska, A., Rekosz-Burlaga, H., Goryluk-Salmonowicz, A., Błaszczyk, M., Stępniewska, Z., 2015. Bacterial abundance and dehydrogenases activity in selected agricultural soils from Lublin region. Polish Journal of Environmental Studies 24(6), 2677-2682. https://doi.org/10.15244/ pjoes/59323

Wyszkowska, J., Borowik, A., Kucharski, M., Kucharski, J., 2013. Effect of cadmium, copper and zinc on plants, soil microorganisms and soil enzymes. Journal of Elementology 18(4), 769-796. https://doi. org/10.5601/jelem.2013.18.4.455

Wyszkowska, J., Kucharski, J., Borowik, A., Boros, E., 2008. Response of bacteria to soil contamination with heavy metals. Journal of Elementology 13(3), 443-453.

Wyszkowska, J., Kucharski, J., Lajszner, W., 2006. The effects of copper on soil biochemical properties and its interaction with other heavy metals. Polish Journal of Environmental Studies 15(6), 927-934.

Wyszkowska, J., Wieczorek, K., Kucharski, J., 2016. Resistance of arylsulfatase to contamination of soil by heavy metals. Polish Journal of Environmental Studies 25(1), 365-375. https://doi.org/10.15244/ pjoes/60417

Yang, Y., Campbell, C.D., Clark, L., Cameron, C.M., Paterson, E., 2006. Microbial indicators of heavy metal contamination in urban and rural soils. Chemosphere 63(11), 1942-1952. https://doi.org/10.1016/j.chemosphere.2005.10.009

Yang, Z.X., Liu, S.Q., Zheng, D.W., Feng, S.D., 2006. Effects of cadium, zinc and lead on soil enzyme activities. Journal of Environmental Sciences 18(6), 1135-1141. https://doi.org/10.1016/S1001-0742(06)60051-X

Yu, S., Zhu, Y.G., Li, X.D., 2012. Trace metal contamination in urban soils of China. Science of the Total Environment 421-422, 17-30. https://doi. org/10.1016/j.scitotenv.2011.04.020

Zhang, X., Li, F., Liu, T., Xu, C., Duan, D., Peng, C., Zhu, S., Shi, J., 2013. The variations in the soil enzyme activity, protein expression, microbial biomass, and community structure of soil contaminated by heavy metals. International Scholarly Research Notices 2013. https://doi. org/10.1155/2013/803150

Zhang, Y.L., Dai, J.L., Wang, R.Q., Zhang, J., 2008. Effects of long-term sewage irrigation on agricultural soil microbial structural and functional characterizations in Shandong, China. European Journal of Soil Biology 44(1), 84-91. https://doi.org/10.1016/j.ejsobi.2007.10.003

Zhao, X., Sun, Y., Huang, J., Wang, H., Tang, D., 2020. Effects of soil heavy metal pollution on microbial activities and community diversity in different land use types in mining areas. Environmental Science and Pollution Research 27(16), 20215-20226. https://doi.org/10.1007/ s11356-020-08538-1

Zhou, H., Yang, W.T., Zhou, X., Liu, L., Gu, J.F., Wang, W.L., Zou, J.L., Tian, T., Peng, P.Q., Liao, B.H., 2016. Accumulation of heavy metals in vegetable species planted in contaminated soils and the health risk assessment. International Journal of Environmental Research and Public Health 13(3), 289. https://doi.org/10.3390/ijerph13030289

Zhuang, P., McBride, M.B., Xia, H., Li, N., Li, Z., 2009. Health risk from heavy metals via consumption of food crops in the vicinity of Dabaoshan mine, South China. Science of the Total Environment 407(5), 1551-1561. https://doi.org/10.1016/j.scitotenv.2008.10.061 